\title{
EL SERVICIO MILITAR OBLIGATORIO EN COLOMBIA
}

Una visión desde el Análisis Económico del Derecho

\section{CT GIOVANI ALEXANDER VARGAS GARCÍA}

Candidato a Magister en Derecho Público

\section{MAURICIO ANTONIO TORRES GUARNIZO}

Director

\author{
UNIVERSIDAD SANTO TOMÁS \\ FACULTAD DE DERECHO \\ MAESTRÍA EN DERECHO PÚBLICO \\ BOGOTA D.C.
}


El servicio militar obligatorio en Colombia Una visión desde el Análisis Económico del Derecho CT Giovani Alexander Vargas García

\section{Agradecimientos:}

A Dios, mi familia y mi Ejército Nacional 


\section{TABLA DE CONTENIDO}

INTRODUCCIÓN 4

I. EL SERVICIO MILITAR OBLIGATORIO EN COLOMBIA

1.1. Antecedentes del servicio militar 11

1.2. El servicio militar en el ordenamiento jurídico colombiano 17

1.2.1. Constitución Política de 1886 - Ley $1^{\text {a }}$ de 1945

1.2.2. Constitución Política de 1991 - Ley 48 de 1993

1.2.3. Ley 1861 de $2017 \quad 30$

1.3. Análisis dinámico del servicio militar en Colombia 34

II. PRINCIPIOS, DERECHOS CONSTITUCIONALES Y $\begin{array}{llllll}\text { SERVICIO MILITAR OBLIGATORIO } & \text { EN LA } & 43\end{array}$ JURISPRUDENCIA CONSTITUCIONAL

2.1. Dignidad humana 45

2.2. Igualdad 51

2.3. Libre desarrollo de la personalidad $\quad 59$

2.4. Solidaridad 65

2.5. Interés general y bien común 70

III. ANÁLISIS ECONÓMICO DEL SERVICIO MILITAR 78

3.1. Análisis económico del derecho 78

3.1.1. Generalidades del análisis económico del derecho 78

3.1.2. Presupuestos del análisis económico del derecho 82

3.1.2.1.Racionalidad del comportamiento de los individuos $\quad 82$

3.1.2.2.Eficiencia como finalidad de las decisiones racionales $\quad 84$

3.1.2.3.Normas como precio $\quad 90$

3.2. Análisis económico del servicio militar obligatorio 91

3.3. Perspectivas y propuestas 99

$\begin{array}{ll}\text { Conclusiones } & 102\end{array}$

$\begin{array}{ll}\text { Bibliografía } & 106\end{array}$ 


\section{EL SERVICIO MILITAR OBLIGATORIO EN COLOMBIA UNA VISIÓN DESDE EL ANÁLISIS ECONÓMICO DEL DERECHO}

\section{INTRODUCCIÓN}

La Constitución Política de 1991 (C. Pol.) establece que Colombia es un Estado Social de Derecho y a lo largo de su articulado se evidencia que el Estado debe direccionar su actividad hacia el cumplimiento de unos fines esenciales y sociales.

En términos generales, para el cumplimiento de ciertos cometidos estatales, el constituyente decidió que la Fuerza Pública en Colombia estará integrada en forma exclusiva por las Fuerzas Militares y la Policía Nacional (artículo 216 C. Pol.). A las Fuerzas Militares, constituidas por el Ejército, la Armada y la Fuerza Aérea, le asignó la finalidad de la defensa de la soberanía, la independencia, la integridad del territorio nacional y del orden constitucional (artículo 217 C. Pol.). Por su parte, la Policía Nacional, como cuerpo de naturaleza civil, tiene como fin primordial el mantenimiento de las condiciones necesarias para el ejercicio de los derechos y libertades públicas, y para asegurar que los habitantes de Colombia convivan en paz (artículo 218 C. Pol.).

En desarrollo de lo anterior, la Carta Magna de 1991, en su artículo 216 estableció que "todos los colombianos están obligados a tomar las armas cuando las necesidades públicas lo exijan para defender la independencia nacional y las instituciones públicas". Así las cosas, en palabras de la Corte Constitucional (2011), se trata de una obligación superior que se deriva del deber genérico impuesto a todos los nacionales respecto del sostenimiento 
y defensa de la soberanía, la guarda de las instituciones y el mantenimiento del orden público (Sentencia C-879).

Con miras a materializar lo estipulado en la Constitución Política en las normas señaladas anteriormente, el legislador expidió la Ley 48 de 1993, la cual se encargó de reglamentar el servicio militar obligatorio, norma que rigió durante veinticuatro (24) años y que fue derogada con la expedición y entrada en vigor de la Ley 1861 de 2017, la cual establece, en su artículo 4, que el servicio militar obligatorio "es un deber constitucional dirigido a todos los colombianos de servir a la patria, que nace al momento de cumplir su mayoría de edad, para alcanzar y cumplir los fines del Estado encomendados a la Fuerza Pública”.

Así las cosas, la Constitución prevé, que el servicio militar obligatorio, no solo se prestará en las Fuerzas Militares, sino que adicionalmente, se prestará en un cuerpo de índole netamente civil, como lo es la Policía Nacional, lo que, a primera vista, desnaturaliza dicha institución.

Dicha situación se agudiza con la expedición de la Ley 1861 de 2017, al establecer, entre otras cosas, que el servicio militar obligatorio se prestará como auxiliar del cuerpo de custodia del Instituto Nacional Penitenciario y Carcelario - INPEC (artículo 15) y que mínimo el diez por ciento (10\%) del personal incorporado para cada contingente, prestará servicio ambiental (artículo 16) en concordancia con la Ley 99 de 1993. 
Lo anterior podría ser problemático desde el punto de vista constitucional, ya que podría entenderse que el legislador a través de la Ley 1861 de 2017 desconoce las finalidades por las cuales se establece el servicio militar obligatorio al ampliar dicha obligación a la custodia de los reclusos en las cárceles colombianas y a la loable protección del medio ambiente.

Otro asunto controversial de relevancia constitucional surge, en virtud que en la Ley 1861 de 2017 se evidencia a priori una violación al principio de igualdad material, en dos aspectos concretos: el tratamiento desigual para la mujer frente al servicio militar obligatorio y el tratamiento inequitativo para aquellos, varones, de menores ingresos, que no pueden acceder a la educación superior.

En torno al primer aspecto, el artículo 11 de la Ley 1861 de 2017 establece que la obligación de definir la situación militar es para los varones, cuando cumplan su mayoría de edad y hasta el día en que cumplan 50 años. A pesar de que el artículo 216 Superior no hace distinción alguna, las mujeres, de acuerdo con el Parágrafo 1 del artículo 4, sólo estarán obligadas “cuando las circunstancias del país lo exijan y cuando el Gobierno nacional lo determine”, de lo contrario podrán prestar el servicio de manera voluntaria.

El segundo asunto se deriva de que el artículo 34 de la Ley 1861 de 2017, establece que una de las causales de aplazamiento para la prestación de servicio militar se configura con el hecho de estar matriculado o cursando estudios de educación superior. 
Lo anterior no sería problemático si el acceso a la educación superior fuera generalizado y no un servicio público (artículo 67 C. Pol.) al cual se accede, principalmente, en relación con la capacidad económica de los individuos. Esta situación, se evidencia en el informe de la Defensoría del Pueblo, en el que se señala, que para el año 2013, el 9,42\% de los soldados bachilleres pertenecía al estrato cero, el $14,75 \%$ al estrato uno, el $54,40 \%$ al estrato dos, el 19,39\% al estrato tres, el 1,9\% al estrato cuatro, el 0,13\% al estrato cinco, y el 0,01\% al estrato seis. Así las cosas, el 78,57\% pertenecen a los estratos más pobres y tan solo el 0,14\% a los más ricos, de allí que "el análisis de las cifras oficiales de reclutamiento (...) permite afirmar que en Colombia la población más reclutada o con más riesgo de reclutamiento pertenece mayoritariamente a los estratos 0, 1 y 2" (Defensoría del Pueblo, 2014, p. 127)

Teniendo en cuenta lo anterior, y que, de acuerdo con el parágrafo del 23 de la Ley 1861 de 2017, los colombianos declarados aptos para prestar servicio militar obligatorio podrán ser incorporados a partir de los dieciocho (18) y hasta faltando un día para cumplir los veinticuatro (24) años de edad, prácticamente la norma excluye a los universitarios de prestar servicio militar. Lo anterior nos lleva a concluir que la obligación de prestar servicio militar obligatorio en Colombia está dirigida exclusivamente a los varones pertenecientes a los estratos más bajos, salvo mínimas excepciones.

Lo anterior, en el marco de un Estado Social de Derecho, en el que se ha entendido que la dignidad humana es la piedra angular del mismo, la cual tiene una triple dimensión de principio, valor y derecho constitucional, y en cuyo contenido se han determinado tres 
elementos esenciales, como lo son "vivir bien", "vivir como se quiere" y "vivir sin humillaciones", y teniendo en cuenta que la obligación del servicio militar solo es obligación para los más pobres afectando indefectiblemente su plan de vida (vivir como se quiere) en virtud de su capacidad económica.

Además de la problemática que genera el servicio militar obligatorio desde la perspectiva jurídica, adicionalmente es importante señalar que también tiene una incidencia desde el aspecto económico. La configuración normativa implica un impacto en la asignación y uso de los recursos en un Estado. Es imperativo que estos recursos, por naturaleza escasos, sean utilizados de manera eficiente, porque pareciera injusto, que en una sociedad como la nuestra con tantas necesidades, los recursos sean desperdiciados o subutilizados.

El Análisis Económico del Derecho constituye una corriente, dentro de la teoría jurídica, que aplica métodos propios de la economía en el razonamiento jurídico, para determinar si las normas son o no eficientes. Así las cosas, las normas que establecen y regulan el servicio militar obligatorio, estructuran una configuración normativa que a priori genera ineficiencia, particularmente por cuanto casi medio millón de colombianos prestan servicio militar obligatorio durante cada periodo de gobierno, en el cual dejen de recibir ingresos, dejan de recibir capacitación o formación, es decir, dejan de ser productivos de manera obligatoria. No existen procesos de selección por competencias de los conscriptos para ejercer diversas actividades en la Fuerza Pública, ni mucho menos un sistema de incentivos. Los costos de incorporación, entrenamiento, logísticos, entre otros, son demasiado elevados y nunca se recuperan. 
El interrogante que surge en este punto que es el centro de la investigación, es si ¿la obligación de prestar servicio militar a un grupo marginado de la sociedad impuesta por el legislador a través de la Ley 1861 de 2017, genera ineficiencia bajo los criterios del Análisis Económico del Derecho?

La hipótesis de solución a la pregunta planteada es que la imposición de la obligación legal de prestar servicio militar obligatorio derivado de la Constitución Política y de los pronunciamientos judiciales, podría afectar principios y derechos constitucionales. Es así como, al hacer una aproximación desde el Análisis Económico del Derecho podría predicarse que la actual asignación de recursos, ahonda la gravosa situación de los menos favorecidos agregándole una carga de manera exclusiva y excluyente, generando mayores costos sociales e individuales que beneficios a los más pobres.

Por lo anterior, el objetivo principal que se persigue con la presente investigación es determinar si la eliminación del servicio militar obligatorio implicaría que la reasignación de los recursos relacionados sería eficiente y se garantizaría el cumplimiento de las finalidades de la Fuerza Pública y en términos generales la observancia de los principios y derechos de los ciudadanos estipulados en la Carta Magna.

Como objetivos específicos, necesarios para cumplir con el objetivo general, se establecen los siguientes: primero: identificar las normas constitucionales y legales que establecen y regulan el servicio militar en Colombia; segundo, determinar a través del análisis jurisprudencial, los principios y derechos que se ven afectados con la institución del servicio 
militar en Colombia; y tercero, aplicar los preceptos del Análisis Económico del Derecho a la institución del servicio militar obligatorio en Colombia.

Para tal efecto, en torno al aspecto metodológico, se utilizarán las herramientas propias del Análisis Económico del Derecho, con un enfoque cualitativo, partiendo del análisis normativo y jurisprudencial, desde lo jurídico, y utilizando el criterio de eficiencia de Kaldor-Hicks, desde lo económico.

El documento tendrá tres (3) partes: en primera medida se identificarán las normas constitucionales, legales y reglamentarias del servicio militar obligatorio en Colombia, y se analizará primordialmente la Ley 1861 de 2017 estableciendo sus aspectos más relevantes y destacando aquellos con relevancia constitucional que se han descrito como problemáticos; como segundo aspecto, se establecerá, a la luz de la dogmática y la jurisprudencia constitucional, si esos aspectos problemáticos son contrarios a la Constitución Política, en torno a ciertos principios y derechos fundamentales relacionados con la institución del servicio militar obligatorio; finalmente, después de la descripción de los elementos esenciales del Análisis Económico del Derecho, que constituirán el marco teórico, se hará un ejercicio de aplicación de los mismos para determinar si la supresión del servicio militar obligatorio constituye una solución eficiente a la problemática jurídica planteada o si existen otras soluciones alternativas que respondan a dicho principio.

\section{CAPÍTULO I}




\section{EL SERVICIO MILITAR EN COLOMBIA}

El presente capítulo presentará un análisis de las normas constitucionales y legales que han establecido y regulado el servicio militar en Colombia, estableciendo las características generales del mismo, en especial, frente a los sujetos pasivos de la obligación que se deriva del mismo.

\subsection{Antecedentes del servicio militar}

La historia y el destino de la humanidad han estado marcados por las guerras. La guerra se funda en una forma colectiva de violencia, entendida como una potencia natural en reacción a una amenaza sobre un objeto material, los cuales pueden ser territorios o recursos o frente a posesiones simbólicas que tienen un valor esencial dentro de la comunidad. (Onfray,2005)

Las guerras han trazado la historia de la humanidad, siendo trasversal a todas las culturas y las civilizaciones, pues se encuentra inscrita dentro de la naturaleza humana. En unos casos para conquistar y/o defenderse de la conquista, en otros casos para independizarse y/o mantener la integridad de los Estados.

La conformación de los ejércitos de tierra y mar, ha dependido básicamente del momento histórico, la organización estatal y las estructuras jurídicas en torno a los derechos y obligaciones. Así las cosas, ha sido una mezcla de voluntarios y forzados, en algunos casos esclavos. 
Normalmente los voluntarios inician una carrera que implica preparación y formación en el arte de la guerra. Por su parte, los forzados, con una escasa preparación, pero que, en virtud de los derechos y obligaciones atribuidos, son vinculados a las filas de los ejércitos.

Allí se enmarca el servicio militar, el cual tiene como finalidad la detención de una amenaza destructiva y catastrófica en pro de mantener la institución jurídico-política. Al respecto Weber (1988) señala que "El Estado es la única instancia legitima para hacer uso de la fuerza con el objeto de cumplir las funciones indicadas: defensa del orden común, en lo interno, y relaciones de paz en las relaciones externas" (p.135).

El servicio militar en la historia, parte desde los albores de la civilización, con el Imperio Egipcio en donde se instauró el servició militar a pequeñas milicias locales entre el año 3110 AC hasta el año 665 AC, con la implantación de un ejército profesional en el imperio nuevo en el año 1567 A.C.

Mientras que en Grecia el servicio militar obligatorio se delimitaba por cuenta del poder socioeconómico en cuya fuerza armada realizaba reclutamientos obligatorios entre las clases menos favorecidas. La infantería se organizaba en dos grupos, la infantería ligera, conformada por asalariados; y la infantería pesada, compuesta por pequeños y medianos propietarios. Por otro lado, las fuerzas de la marina se encontraban conformada por hombres libres y por esclavos mantenidos por el Estado. Finalmente, la caballería, conformada por las clases más favorecidas, quienes se encargaban del caballo y su manutención. 
En Roma, los sistemas de reclutamiento pasaron de la fase aristocrática y obviamente voluntaria, es decir un privilegio para algunos, a una fase popular y forzosa para todos los ciudadanos entre diecisiete (17) y cuarenta y seis (46 años), quienes debían completar al menos diez campañas en la caballería o veinte en infantería lo cual mantenía vigente un aspecto socio económico, en la medida en que quienes hacían parte de la caballería era pertenecientes a la clase alta y por su parte, la clase baja constituía las filas de la infantería.

El sistema obligatorio va cambiando a finales del periodo republicano, en el cual se impone el reclutamiento voluntario. La reforma de Mario lo consagra definitivamente. La reforma de Augusto lo mantiene, si bien, reafirma el derecho de Roma al reclutamiento forzoso, incluso en las provincias (Política Exterior S.A., 1992).

Con la caída del imperio Romano comienza la Edad Media, caracterizada por un cambio de sistema económico y político con la entrada del feudalismo. El servicio militar se ve caracterizado una prestación personal del vasallo, quienes no profesionalizados, se equipaban y organizaban como un ejército. Este servicio militar se ve referenciado por un localismo, pues se conservan en cada uno de los feudos europeos.

Con la Revolución Francesa, la concepción del servicio militar cambia en dos aspectos: se abre el oficialato a las clases medias y por otro lado se trata de formar un ejército de soldados y ciudadanos conocedor de las leyes del ordenamiento jurídico (Política Exterior S.A., 1992). 
Con la entrada del Estado moderno fundado en un orden constitucional reconociéndose en las constituciones derechos y deberes; los primeros se reconocen como expresión de la naturaleza humana y los segundos como todas las conductas o actuaciones que la Constitución impone o dirige formalmente a los individuos o a los ciudadanos (Revorio, 2011, p. 286).

Bajo esta dinámica se consagra en la mayoría de Estados Constitucionales la obligatoriedad del servicio militar en desarrollo de principio de solidaridad de los ciudadanos para con el Estado.

A nivel mundial, las Fuerzas de Defensa de Israel - FDI, poseen unas características interesantes sobre todo si se tiene en cuenta la influencia cultural y religiosa tan marcada a lo largo de su historia y que ha sido obligatorio y con un tiempo de servicio muy estricto y relativamente largo en comparación con otras Fuerzas Militares. A partir del año 2000, la legislación otorgó el derecho de las mujeres a servir en diversos roles de las Fuerzas de Defensa de Israel (FDI) en igualdad de derechos frente a los hombres. Se puede decir que Israel, ha logrado un avance sociocultural, donde las personas adquieren un sentido de pertenencia bastante arraigado hacia sus instituciones públicas, cuya legislación prevé la prestación del servicio militar obligatorio para los hombres (36) meses como para las mujeres (24) meses, en un plano de igualdad material, donde el concepto de soberanía y defensa recae en el total de la población, y a pesar de existir exenciones, el deseo de apoyar al Ejército hace que en muchas ocasiones tanto mujeres como hombres no hacen uso de este derecho por el compromiso que se tiene frente al Estado (Rengifo, 2016). 
Por otra parte, en el contexto latinoamericano como en el caso de Argentina, el servicio militar tuvo obligatoriedad desde comienzos del siglo XX hasta que, en 1994, mediante decreto del Poder Ejecutivo Nacional, se suspendió el servicio militar obligatorio remplazándolo por un sistema de tropas voluntarias y profesionalizadas sean varones o mujeres entre dieciocho (18) y veintiséis (26) años de edad, formarán parte y profesionalizadas salvo en un eventual caso de emergencia se permite el reclutamiento obligatorio (Vásquez, 2017).

En México, existe la obligación de prestar el servicio militar nacional, exclusivamente a los varones por nacimiento obligación que termina el 31 de diciembre del año en que los varones cumplen cuarenta (40) años de edad, configurada por un registro inicial y finalmente con la obtención de la cartilla del servicio militar expedida por la Secretaría de la Defensa Nacional luego de la prestación de dicho servicio, ya sea en México o en el extranjero. (Vásquez, 2017)

En Chile, desde abril de 2006, propende por satisfacer un cupo de soldados determinados en las fuerzas armadas que en principio se compone con jóvenes voluntarios salvo que no se completen los cupos requeridos, y se aplica la obligatoriedad en subsidio, seleccionados a través de un proceso de sorteo, bajo condiciones de justicia y transparencia, a través del denominado Sorteo General, el cual se hace de manera pública y aleatoria, bajo vigilancia de las entidades de control respectivas, durante la primera quincena del mes de octubre de cada año. 
La normatividad chilena también hace alusión de la prestación del servicio militar voluntario para las mujeres que se encuentren entre los 17 a los 24 años de edad, quienes lo pondrán hacer en el Ejército, Fuerza Aérea o la Armada. Las jóvenes chilenas que ingresen a estas fuerzas, cuentan con los mismos beneficios que tienen los hombres, ya que pueden nivelar sus estudios y realizar cursos de capacitación laboral, e igualmente se pueden postular como soldados profesionales o acceder a las diferentes escuelas matrices de las Fuerzas Armadas.

La duración del servicio militar voluntario femenino es de 12 meses en el Ejército y la Fuerza Aérea y de 22 meses en la Armada, figura recientemente creada en el año 2018. La duración de instrucción y aprendizaje es el mismo para hombres y mujeres, todas estas medidas buscan el aporte de la mujer en todas las áreas de la sociedad donde estas han demostrado su competencia y profesionalismo.

Lo anterior nos lleva a vislumbrar, que a través de la historia de la humanidad, el servicio militar ha sido instaurado por una necesidad latente de los grupos humanos, hoy Estados, de garantizar la integración constante del personal necesario al pie de fuerza de los ejércitos y las armadas, pero también, que esta necesidad cada vez es menor y por lo menos debería analizarse desde una perspectiva de un Estado Social de Derecho, en términos de igualdad y dignidad humana, sin olvidar la necesidad de seguridad y defensa del Estado y el deber de los ciudadanos con la misma. 


\subsection{El servicio militar en el ordenamiento jurídico colombiano}

\subsubsection{Constitución Política de 1886 - Ley $1^{\text {a }}$ de 1945}

La Constitución de 1886 establecía en su artículo 165 que, “todos los colombianos están obligados a tomar las armas cuando las necesidades públicas lo exijan, para defender la independencia nacional y las instituciones patrias”, pero con un carácter obligatorio a la prestación del servicio militar en Colombia, ya que establecía que la Ley determinaría las condiciones que eximían de la prestación de dicho servicio. Así las cosas, sin que existiera una ley que regulara la materia, todo colombiano estaba obligado a inscribirse para la prestación del servicio militar obligatorio, sin que tuviera exención o aplazamiento (Serrano, 1886).

Con la promulgación de la Ley $1^{\mathrm{a}}$ de 1945, se reguló la prestación del servicio militar en Colombia. Fue la primera ley que determinó quienes estarían en la obligación de prestar el servicio militar de carácter obligatorio en Colombia. El artículo 3 de la mencionada ley, establecía que "todo varón colombiano que se halle comprendido entre los 20 y los 50 años, está obligado a prestar el servicio militar en el Ejército”, así mismo establecía que “ningún varón colombiano declarado apto y sin causa legal de exención, a quien por suerte corresponda prestar el servicio militar, puede eximirse de hacerlo; en consecuencia, no se aceptan reemplazos ni compensaciones pecuniarias de ninguna clase" (Congreso de la República, Ley 1 de 1945, art. 5). 
Sin embargo, se preveía que un menor de edad podía ingresar al servicio para el cumplimiento de sus deberes militares. De ser así, quedaba excluido de la patria potestad, mientras dependía directamente de las autoridades militares (Congreso de la República, Ley 1 de 1945, art. 42).

El servicio militar como soldado en el Ejército de primera línea, tenía una duración de un (1) año, salvo que el gobierno, en caso de necesidad manifiesta, podría extenderlo hasta dos (2) años. A partir de allí, pasara a las reservas de primera y segunda clase hasta el 31 de diciembre del año en que cumple los 30 años de edad. Luego será reservista desde el $1^{\circ}$ de enero del año en que el individuo cumple los 31 años de edad, hasta el 31 de diciembre del año en que cumple los 40. Y finalmente, como reservista del Ejército de tercera línea o Guardia Territorial, desde el $1^{\circ}$ de enero del año en que cumple los 41 años de edad, hasta el 31 que cumple los 41 años de edad, hasta de diciembre del año en que cumple los 50 (Congreso de la República, Ley 1 de 1945, art. 3).

Para la elección del personal de conscriptos que conformarían los respectivos contingentes, y que por ende ingresaban a prestar el servicio activo, se utilizaba el procedimiento de sorteo entre los varones colombianos declarados aptos por los oficiales de sanidad. Adicionalmente, por cada conscripto, se sorteaban dos suplentes. El sorteo no se aplicaba, cuando el número de conscriptos hábiles que debía ser seleccionado en cada municipio, era igual o menor al número de conscriptos requeridos para conformar el contingente (Congreso de la República, Ley 1 de 1945, art. 4). 
Es de anotar que, para cumplir con su obligación de prestar servicio militar, se requería a todo varón colombiano a inscribirse para el servicio militar obligatorio dentro del año que cumple los 19 años de edad. Adicionalmente, "para asegurar el cumplimiento de las obligaciones que se deducen de la inscripción, los ciudadanos deberán otorgar fianza personal ante las autoridades del servicio territorial" (Congreso de la República, Ley 1 de 1945, art. 17).

Para los varones colombianos entre los 21 y los 50 años, no cumplir con la obligación de haber definido su situación militar, podría tener consecuencias en diferentes ámbitos que incluían (1) la prohibición de otorgar instrumentos públicos o privados ante el Notario, (2) tomar posesión de empleos públicos o particulares, y continuar en el desempeño de estos, (3) cobrar sueldos, emolumentos o deudas del Tesoro Público. Tampoco podían (4) servir de perito o de fiador en asuntos judiciales o civiles, (5) ni obtener o refrendar pases o licencias para conducir vehículos, (6) obtener la expedición de pasaportes para salir del país, (7) registrar títulos profesionales ni ejercer la profesión. Era un impedimento para (8) ingresar a la carrera administrativa y (9) para celebrar contratos con cualquiera entidad pública (Congreso de la República, Ley 1 de 1945, art. 6).

Lo anterior evidenciaba claramente que la obligación constitucional del artículo 165, en desarrollo del principio de interés general, era entendida como trascendental en el ordenamiento jurídico colombiano, ya que su incumplimiento acarreaba consecuencias en ámbitos, que hoy parecen impensables. 
Así, se demostraba la importancia y la relación directa entre la ciudadanía y su obligación de hacer parte del Ejército, de su obligación de defender la patria, afectando la libertad económica, la libertad de empresa, el derecho al trabajo y el derecho de locomoción, entre otros.

Sin embargo, la ley también preveía excepciones. Frente a quienes se encontraban exentos de prestar el servicio militar obligatorio, se encontraban clasificados en dos grupos: aquellos que estaban obligados a pagar la cuota de compensación militar y aquellos que no lo estaban. La cuota de compensación militar, que se paga una sola vez por los individuos que no presten el servicio militar, es la contribución pecuniaria que debe pagarse al tesoro nacional, por concepto de la obligación militar (Congreso de la República, Ley 1 de 1945, art. 32).

El artículo 20 de la Ley $1^{\text {a }}$. de 1945 contempló que estarían exentos de la prestación del servicio militar, y además no tendrían la obligación de pagar cuota de compensación dos grandes grupos de ciudadanos. Por un lado, (1) los clérigos católicos, seculares y regulares; los miembros de congregaciones católicas religiosas y docentes; y los seminaristas o estudiantes de teología de establecimientos reconocidos por el Estado. Por otro lado, (2) los inhábiles absolutos.

Por su parte, la ley también estableció que estarían exentos de prestar el servicio militar en tiempos de paz y pero que tendrían la obligación de inscribirse y pagar cuota de compensación: (1) los condenados a una pena que tuviera como accesoria la pérdida de derechos políticos; (2) los hijos de las viudas que observen buena conducta; (3) los huérfanos 
de padre que atendiera con su trabajo la subsistencia de sus hermanos; (4) los hijos de padres incapacitados para trabajar o mayores de 60 años y que carecieran de pensión o renta; (5) los hermanos o hijos de quienes hayan muerto prestando el servicio militar; (6) los viudos que sostengan a los hijos habidos en el matrimonio; (7) los hijos únicos huérfanos de padre con hermanas solteras o hermanos menores que estén a su cargo; (8) los inhábiles relativos permanentes (Congreso de la República, Ley 1 de 1945, art. 21).

Finalmente, la ley permitía que algunos ciudadanos aplazaran el servicio militar. Este aplazamiento se mantenía por el tiempo en que subsistieran una de las siguientes circunstancias: ser hermano de quien estuviese prestando el servicio militar obligatorio, encontrarse detenido previamente por las autoridades civiles en la época en que debía ser sorteado, y resultar inhábil relativo temporal, en cuyo caso quedaba aplazado o pendiente de nuevo reconocimiento hasta el año siguiente, y si en dicho año subsistía la inhabilidad, se le clasificaba definitivamente para el pago de la cuota de compensación militar (Congreso de la República, Ley 1 de 1945, art. 22).

Además de lo anterior, el artículo 23 de la mencionada norma, establecía que los estudiantes tenían derecho a aplazamientos anuales sucesivos, hasta la terminación de los estudios reglamentarios profesionales y a dos años más después de terminados. Una vez, obtuvieran título universitario, se considerarían como oficiales de reserva.

La obligación de la mujer en torno al servicio militar obligatorio era nula. Salvo en caso de guerra internacional, en el cual los colombianos de ambos sexos, no comprendidos dentro del llamamiento de filas, "podrán ser forzosamente utilizados según sus aptitudes y 
facultades en trabajos en trabajos en los cuales puedan prestar eficaces servicios al éxito de la guerra" (Congreso de la República, Ley 1 de 1945, art. 51). Esta misma norma, facultaba al Gobierno para que estableciera la forma en que las mujeres debían preparase para los servicios auxiliares en tiempo de guerra.

Es de anotar, que en vigencia de la Constitución de 1886 se expidió la Ley 131 de 1985 con la cual se reguló la prestación del servicio militar voluntario en Colombia. Esta norma introdujo la posibilidad para quienes, habiendo prestado el servicio militar obligatorio, sean aceptados por la respectiva Fuerza, de prestar el servicio militar voluntario durante un periodo que no podía ser inferior a doce (12) meses (Congreso de la República, Ley 131 de 1985, art. 2).

En su artículo $3^{\circ}$ aclaró que quienes prestaran el servicio militar voluntario estarían sujetos al Código de Justicia Penal Militar, al Reglamento de Régimen Disciplinario, al Régimen Prestacional y en general a todas las normas para los soldados de las Fuerzas Militares y los reglamentos especiales expedidos.

Adicionalmente, quien preste el servicio militar voluntario devengará una bonificación mensual equivalente al salario mínimo legal vigente, incrementada en un sesenta por ciento (60\%) del mismo salario, es decir el $160 \%$ de un salario mínimo mensual.

Lo anterior implica que no existe una relación laboral entre los soldados voluntarios (ni los conscriptos) y el Estado, en virtud de que lo que la norma establece el pago de una remuneración y no de un salario por su servicio. 


\subsubsection{Constitución de 1991 - Ley 48 de 1993}

La Constitución de 1991 significó un cambio estructural trascendental en la manera en que el Estado y sus ciudadanos se relacionan, fundamentado en los principios de un Estado Social de Derecho. Sin embargo, estos cambios no generaron modificaciones normativas significativas inmediatas frente a la obligación de la prestación del servicio militar obligatorio, aun cuando estas se fueron presentando a lo largo de los últimos veinte (20) años, pero de manera paulatina, en asuntos como la objeción de conciencia y el papel de la mujer en las Fuerzas Armadas, principalmente.

La Constitución Política de 1991 señala en su artículo 216 que "la fuerza pública estará integrada en forma exclusiva por las Fuerzas Militares y la Policía Nacional” Así mismo señala, frente al servicio militar obligatorio que "Todos los colombianos están obligados a tomar las armas cuando las necesidades públicas lo exijan para defender la independencia nacional y las instituciones públicas”, es decir que mantuvo la fórmula del artículo 165 de la Constitución de 1886.

Por su parte, el artículo $2^{\circ}$ de la Carta Magna establece que entre los fines esenciales del Estado Social de Derecho se encuentran, la defensa de la independencia nacional, el mantenimiento de la integridad territorial, el aseguramiento de la convivencia pacífica y la vigencia de un orden justo. En concordancia con lo anterior, los artículos 216 y 217 de la Constitución Política de Colombia disponen que las Fuerzas Militares, responden entonces al objetivo superior de asegurar esos cometidos constitucionales. 
En el caso del servicio militar, según lo preceptuado por el artículo 216 Constitucional, éste se encuentra concebido como una forma de responsabilidad social que se conserva entre la sociedad civil y el Estado.

Dicho de otra manera: es la posibilidad de que el ciudadano participe en la tarea de asegurar la convivencia pacífica de los habitantes del territorio colombiano, sin que ello propiamente implique una vulneración a los derechos de los particulares, en la medida en que su esencia materializa el ejercicio de la solidaridad ciudadana en un servicio especial e impostergable que requiere, en todos los tiempos, la sociedad (Corte Constitucional, Sentencia T-224 de 1993. M.P. Vladimiro Naranjo Mesa).

Sin embargo, esta fórmula debía ser conciliada y entendida dentro de una nueva estructura constitucional, lo que dio como origen a la Ley 48 de 1993, la cual debería incorporar las nuevas lógicas constitucionales, así como ciertos estándares internacionales, como, por ejemplo, los establecidos en la Convención de los Derechos del Niño de la ONU de 1989. Así, la Ley 48 de 1993 y el Decreto 2048 de 1993 reglamentario de la mencionada ley, constituyeron el régimen legal del servicio de reclutamiento y movilización.

La norma consagró la obligación expresa de todo varón colombiano de "definir su situación militar a partir de la fecha en que cumpla su mayoría de edad, a excepción de los estudiantes de bachillerato, quienes definirán cuando obtengan su título de bachiller”. (Congreso de la República, Ley 48 de 1993, art. 10). 
Sin embargo, el primer gran cambio que se da en este aspecto, es el de la posibilidad de la prestación del servicio militar voluntario por parte de las mujeres. El parágrafo del artículo 10 establece que "la mujer colombiana prestará el servicio militar voluntario, y será obligatorio cuando las circunstancias del país lo exijan y el Gobierno Nacional lo determine".

Las modalidades actuales sobre la prestación del servicio militar son básicamente cuatro (4): como soldado regular, como soldado bachiller, como soldado campesino y como auxiliar de policía. La duración en la prestación del servicio dependía claramente de la modalidad de la prestación. La obligación de doce (12) meses, para los soldados bachilleres y para los auxiliares de policía. La obligación entre doce (12) y dieciocho (18) meses para los soldados campesinos. Y entre dieciocho (18) y veinticuatro (24) meses para los soldados regulares (Congreso de la República, Ley 48 de 1993, art. 12-13).

La Ley 99 de 1993 estableció la creación del servicio ambiental el cual tiene por objeto prestar apoyo a las autoridades ambientales, a las entidades territoriales y a la comunidad en la defensa y protección del medio ambiente y los recursos naturales renovables. A su vez, se estableció que el veinte por ciento (20\%) de los bachilleres seleccionados para prestar el Servicio Militar Obligatorio, prestarán servicio ambiental, preferiblemente entre quienes acrediten capacitación en asuntos ambientales. Las funciones que deben cumplir se refieren a educación ambiental, organización comunitaria para la gestión ambiental y prevención, control y vigilancia sobre el uso del medio ambiente y los recursos naturales renovables (Congreso de la República, Ley 99 de 1993, art. 102). 
Todo varón colombiano tenía la obligación de inscribirse para definir su situación militar dentro del año anterior en que cumpliera la mayoría de edad. Una vez inscrito y aprobado los exámenes de aptitud psicofísica, la elección para la incorporación de contingentes, se hacía por el procedimiento de sorteo público entre los conscriptos aptos, en los que se sorteaban un principal y un suplente, salvo en los casos en los que no era suficiente el número de conscriptos, situación en la que no se adelantaba sorteo alguno (Congreso de la República, Ley 48 de 1993, art. 14 y ss.). La incorporación de los conscriptos se efectuaba a partir de la mayoría de edad hasta cuando cumpla 28 años (Congreso de la República, Ley 48 de 1993, art. 20). Sin embargo, en virtud del artículo 19 de la Ley 1780 de 2016, los conscriptos podrían ser incorporados a partir de la mayoría de edad hasta faltando un día para cumplir los veinticuatro (24) años de edad.

Al igual que bajo el régimen anterior, existían exenciones y aplazamientos. En este punto se presentaron varios cambios significativos. En primer lugar, se determinó que estarían exentos de prestar el servicio militar en todo tiempo y no pagarían cuota de compensación militar: (1) los limitados físicos y sensoriales permanentes, y (2) los indígenas que residan en su territorio y conserven su integridad cultural, social y económica (Congreso de la República, Ley 48 de 1993, art. 27).

Por su parte, el artículo 28 de la Ley 48 de 1993 establece que están exentos del servicio militar con la obligación de inscribirse y pagar cuota de compensación militar: (1) los clérigos y religiosos; (2) los que hubieren sido condenados a penas que tengan como accesorias la pérdida de los derechos políticos mientras no obtengan su rehabilitación; (3) los 
hijos únicos; (4) los huérfanos de padre o madre que atienda con su trabajo a la subsistencia de sus hermanos incapaces de ganarse el sustento; (5) los hijos de padres incapacitados para trabajar o mayores de 60 años, cuando éstos carezcan de renta, pensión o medios de subsistencia, siempre que dicho hijo vele por ellos; (6) los casados que hagan vida conyugal y quienes convivan en unión permanente de acuerdo con la ley (Corte Constitucional, Sentencia C-775 de 2008. M.P. Nelson Pinilla Pinilla); (7) los inhábiles relativos y permanentes; (8) los hermanos o hijos de quien haya muerto o adquirido una inhabilidad absoluta y permanente en combate, en actos del servicio o como consecuencia del mismo, durante la prestación del servicio militar obligatorio; (9) los hijos de oficiales, suboficiales, agentes y civiles de la Fuerza Pública que hayan fallecido o adquirido una inhabilidad absoluta y permanente en combate o en actos del servicio y por causas inherentes al mismo.

Así mismo se señalan las causales de aplazamiento la prestación del servicio militar las siguientes: (1) ser hermano de quien esté prestando servicio militar obligatorio; (2) encontrarse detenido preventivamente por las autoridades civiles en la época en que deba ser incorporado; (3) resultar inhábil relativo temporal, en cuyo caso queda pendiente de un nuevo reconocimiento hasta la próxima incorporación. Si subsistiere la inhabilidad, se clasificará para el pago de la cuota de compensación militar; (4) haber sido aceptado o estar cursando estudios en establecimientos reconocidos por las autoridades eclesiásticas como centros de preparación de la carrera sacerdotal o de la vida religiosa; (5) ser aspirante a ingresar a las escuelas de formación de Oficiales, Suboficiales y Agentes; (6) estar inscrito para la prestación del servicio militar, y no obtuviere el título de bachiller por pérdida del año (Congreso de la República, Ley 48 de 1993, art. 29). 
Una causal de aplazamiento que no regulaba la Ley 48 de 1993, fue establecida por la Ley 418 de 1997. Esta norma tenía por objeto “dotar al Estado colombiano de instrumentos eficaces para asegurar la vigencia del Estado Social y Democrático de Derecho y garantizar la plenitud de los derechos y libertades fundamentales reconocidos en la Constitución Política y/o los Tratados Internacionales aprobados por Colombia” (Congreso de la República, Ley 418 de 1997, art. 1). La mencionada ley establecía que “los menores de 18 años de edad no serán incorporados a filas para la prestación del servicio militar”.

Sin embargo, a los estudiantes de undécimo grado, menores de edad que, conforme a la Ley 48 de 1993, resultaran elegidos para la prestación del servicio militar, se les aplazaba su incorporación a las filas hasta el cumplimiento de la mayoría de edad. Adicionalmente, sí al cumplir la mayoría de edad, el joven que hubiese aplazado su servicio militar, estuviese matriculado en un programa de pregrado en institución de educación superior, tendrá la opción de aplazarlo nuevamente, para el momento de la terminación de sus estudios. La interrupción de los mismos haría exigible la obligación de incorporarse al servicio militar (Congreso de la República, Ley 418 de 1997, art. 13).

Es de anotar que esta norma tenía una vigencia de dos (2) años (Congreso de la República, Ley 418 de 1997, art. 132), razón por la esta ley fue prorrogada por tres (3) años, contados a partir de la sanción de la Ley 548 de 1999. Las leyes 782 de 2002, 1106 de 2006, 1421 de 2010 y 1738 de 2014, prorrogaron la vigencia de esta disposición por términos sucesivos de cuatro (4) años. 
Al igual que en vigencia de la Constitución de 1886, bajo la nueva Carta Magna, en virtud de la Ley 48 de 1993, para los colombianos hasta los 50 años, no cumplir con la obligación de haber definido su situación militar, podría tener consecuencias en diferentes ámbitos. Las consecuencias negativas se disminuyeron, pero permanecieron las siguientes: (1) celebrar contratos con cualquier entidad pública; (2) ingresar a la carrera administrativa; (3) tomar posesión de cargos públicos, y (4) obtener grado profesional en cualquier centro docente de educación superior (Congreso de la República, Ley 48 de 1993, art. 36).

Sin embargo, esta última situación fue contemplada por el artículo 13 de la Ley 418 de 1997, la cual establecía que “ninguna institución de educación superior podrá exigir como requisito para obtener título de pregrado el presentar libreta militar" norma que como se mencionó anteriormente, fue prorrogada por las leyes 782 de 2002, 1106 de 2006, 1421 de 2010 y 1738 de 2014. Finalmente, la normativa establece que todo conscripto tiene derecho, desde el día de su incorporación hasta la fecha del licenciamiento, a ser atendido por cuenta del Estado, en todas sus necesidades básicas atinentes a salud, alojamiento, alimentación, vestuario, bienestar y disfrutará de una bonificación mensual (Congreso de la República, Ley 48 de 1993, art. 39).

Lo anterior implica que se mantiene la inexistencia de una relación laboral entre los soldados conscriptos y el Estado, en virtud que la norma establece el pago de una bonificación y no de un salario por su servicio. 
Para el caso de los soldados voluntarios, en virtud de la Ley 578 de 2000 y el Decreto 1793 de 2000, su relación con el Estado se enmarca en el de una relación laboral, en virtud de que reciben un salario y demás prestaciones sociales, propias de este tipo de vínculos.

\subsubsection{Ley 1861 de 2017}

El Congreso de la República decidió expedir una nueva norma que se encargara de reglamentar el servicio de reclutamiento, control de reservas y la movilización en Colombia. Esta norma, mantiene el servicio militar obligatorio, pero hace una serie de cambios que intentan adecuar las normas legales a decisiones jurisprudenciales que han de una u otra manera, afectado la forma en que se entiende y se configura el servicio militar obligatorio en Colombia.

Esta norma define el servicio militar obligatorio como "un deber constitucional dirigido a todos los colombianos de servir a la patria, que nace al momento de cumplir su mayoría edad para contribuir y alcanzar los fines del Estado encomendados a la Fuerza Pública” (Congreso de la República, Ley 1861 de 2017, art. 4).

La Ley mantiene la obligación en cabeza de todo varón colombiano de definir su situación militar como reservista de primera o segunda clase, a partir de la fecha en que cumpla su mayoría de edad y hasta el día en que cumpla 50 años de edad (Congreso de la República, Ley 1861 de 2017, art. 11). Igualmente, esta nueva norma, da continuidad a la posibilidad de la prestación del servicio militar voluntario por parte de las mujeres (Congreso de la República, Ley 1861 de 2017, art. 4). 
No obstante varía, en términos generales, la duración del servicio, regularizándola en dieciocho (18) meses, salvo para los bachilleres para quienes se mantendrá el período de doce (12) meses (Congreso de la República, Ley 1861 de 2017, art. 13). Es muy importante señalar que, de acuerdo con la nueva normativa, el servicio militar incluye cuatro (4) fases: (1) formación militar básica; (2) formación laboral productiva; (3) aplicación práctica y experiencia de la formación militar básica; (4) descansos. La fase de formación laboral productiva no aplica para los soldados bachilleres. Esta fase será proporcionada por el Servicio Nacional de Aprendizaje - SENA.

El servicio militar obligatorio se prestará como soldado en el Ejército, infante de marina en la Armada Nacional, soldado de aviación en la Fuerza Aérea, auxiliar de policía en la Policía Nacional y auxiliar del Cuerpo de Custodia en el Instituto Nacional Penitenciario y Carcelario - INPEC (Congreso de la República, Ley 1861 de 2017, art. 15). Esta última posibilidad, es una novedad frente al servicio militar que incorpora la nueva norma.

La norma evidencia, la decisión del legislador de asignar mínimo el diez por ciento (10\%) del personal incorporado por cada contingente para que preste servicio ambiental, preferiblemente entre quienes certifiquen capacitación y/o conocimientos en asuntos ambientales. Dicha figura incorporada por el Decreto 2811 de 1974 y desarrollado en la Ley 99 de 1993, no se materializó en vigencia de la Ley 48 de 1993, implica que el servicio militar obligatorio se puede prestar en labores ajenas a las tradicionalmente asignadas a las Fuerzas Militares (Congreso de la República, Ley 1861 de 2017, art. 16). 
Quienes sean declarados aptos para prestar el servicio militar obligatorio podrán ser incorporados a partir de la mayoría de edad, hasta faltando un día para cumplir los veinticuatro (24) años de edad (Congreso de la República, Ley 1861 de 2017, art. 23).

El artículo 12 de la Ley 1861 de 2017, en torno a los exonerados de prestar el servicio militar obligatorio, mantuvo los siguientes casos: (1) los hijos únicos, hombre o mujer; (2) los padres de familia; (3) los huérfanos de padre o madre que atienda con su trabajo a la subsistencia de sus hermanos incapaces de ganarse el sustento; (4) los hijos de padres incapacitados para trabajar o mayores de 60 años, cuando estos carezcan de renta, pensión o medios de subsistencia, siempre que dicho hijo vele por ellos; (5) hermanos o hijos de quien haya muerto o adquirido una inhabilidad absoluta y permanente en combate, en actos del servicio o como consecuencia del mismo, durante la prestación del servicio militar obligatorio; (6) hijos de oficiales, suboficiales, soldados e infantes de Marina profesionales, agentes, nivel ejecutivo y de la Fuerza Pública que hayan fallecido, o que los organismos y autoridades médico-laborales militar o de policía hayan declarado su invalidez, en combate o en actos del servicio y por causas inherentes al mismo; (7) los clérigos y religiosos; (8) los casados que hagan vida conyugal; (9) quienes acrediten la existencia de unión marital de hecho legalmente declarada; (10) las personas en situación de discapacidad física, psíquica, o sensorial permanente; (11) los indígenas que acrediten su integridad cultural, social y económica. 
Esta misma norma, además incluyó como exentos de presentar el servicio militar obligatorio a quienes cumplan las siguientes condiciones: (1) los varones colombianos que después de su inscripción hayan dejado de tener el componente de sexo masculino en su registro civil; (2) las víctimas del conflicto armado que se encuentren inscritas en el Registro Único de Víctimas (RUV); (3) los ciudadanos incluidos en el programa de protección a víctimas y testigos de la Fiscalía General de la Nación; (4) los ciudadanos objetores de conciencia; (5) los ciudadanos desmovilizados, previa acreditación de la Agencia Colombiana para la Reintegración (Congreso de la República, Ley 1861 de 2017, art. 12).

En torno a los aplazamientos la norma compila lo establecido previamente en la Ley 48 de 1993 y la Ley 418 de 1997. Reitera las causales de aplazamiento para la prestación del servicio militar así: (1) ser hermano de quien esté prestando servicio militar obligatorio; (2) encontrarse cumpliendo medida de aseguramiento; (3) los condenados a penas que impliquen la pérdida de los derechos políticos; (4) haber sido aceptado o estar cursando estudios en establecimientos reconocidos como centros de preparación de la carrera sacerdotal o de la vida religiosa; (5) haber alcanzado la mayoría de edad, estar aceptado y cursando estudios de primaria, secundaria o media. (6) haber sido aceptado y estar cursando como estudiante en las Escuelas de Formación de Oficiales, Suboficiales y Nivel Ejecutivo de la Fuerza Pública; (7) estar matriculado o cursando estudios de educación superior (Congreso de la República, Ley 1861 de 2017, art. 34). 
Finalmente, la norma establece que todo conscripto tiene derecho, desde el día de su incorporación hasta la fecha del licenciamiento, a ser atendido por cuenta del Estado, en todas sus necesidades básicas atinentes a salud, alojamiento, alimentación, vestuario, bienestar y disfrutará de una bonificación mensual hasta por el 30\% del salario mínimo mensual vigente, la cual podrá llegar hasta el 50\%, de acuerdo con la disponibilidad presupuestal (Congreso de la República, Ley 1861 de 2017, art. 44).

\subsection{Análisis dinámico del servicio militar obligatorio en Colombia}

En el marco de un Estado Social de Derecho, es imperativa la existencia de las Fuerzas Armadas, para garantizar su existencia y seguridad, ante una serie de situaciones que puedan llegar a poner en riesgo la paz nacional, su organización política, democrática, social y económica. De acuerdo con el artículo 217 de la Constitución Política de 1991, “la Nación tendrá para su defensa unas Fuerzas Militares permanentes constituidas por el Ejército, la Armada y la Fuerza Aérea", las cuales tendrán como finalidad primordial "la defensa de la soberanía, la independencia, la integridad del territorio nacional y del orden constitucional”.

Por su parte, al artículo 218 de la Carta Magna, establece que:

"La Policía Nacional es un cuerpo armado permanente de naturaleza civil, a cargo de la Nación, cuyo fin primordial es el mantenimiento de las condiciones necesarias para el ejercicio de los derechos y libertades públicas, y para asegurar que los habitantes de Colombia convivan en paz". 
Bajo este marco normativo y teniendo en cuenta las obligaciones que tienen los ciudadanos para con su patria, es necesario analizar la evolución del servicio militar obligatorio en Colombia, descrito, principalmente en las leyes $1^{\text {a }}$ de 1945, 48 de 1993 y 1816 de 2017.

En términos generales. los sujetos obligados han sido permanentemente los varones colombianos. Su obligación siempre se ha mantenido hasta los 50 años, sin embargo, los términos de incorporación si han sufrido cambios. En vigencia de la Ley $1^{\text {a }}$ de 1985 , se incorporaban inclusive menores de edad, aunque su obligación surgía con la mayoría de edad, que era de veintiún (21) años. Con la entrada en vigencia de la nueva Constitución Política la mayoría de edad de dieciocho (18) años se convirtió en la edad mínima de incorporación, aunque inicialmente se permitía la incorporación de menores, estándares internacionales y normas modificatorias de la Ley 48 de 1993 establecieron dicho criterio. Por su parte, la edad máxima de incorporación si ha variado significativamente, pasando de los treinta (30) años de edad bajo la Ley $1^{\mathrm{a}}$ de 1985, a los veintiocho (28) en virtud de la Ley 48 de 1993, hasta llegar a los veinticuatro (24).

Las mujeres nunca se han encontrado, ni se encuentran obligadas a prestar servicio militar en Colombia, como sí sucede en otros países. En vigencia de la Constitución de 1886, no se preveía que las mujeres hicieran parte orgánica de las tropas de las Fuerzas Militares. La participación de la mujer se limitaba a casos de guerra, pero únicamente para desempeñar tareas de asistencia y auxilio. Con la entrada en vigor de la Constitución de 1991, se previó que la mujer prestara servicio militar voluntario y obligatorio en caso de guerra. 
Otro aspecto esencial, es el referente a las exenciones y a los aplazamientos. Es decir, aquellos que no se encuentran obligados a prestar el servicio militar y/o aquellos que estando obligados por ciertas circunstancias tienen derecho a que su situación militar y por ende la prestación de servicio militar en sí mismo se preste con posterioridad al cumplimiento de la mayoría de edad o cuando nace su obligación.

A continuación, se sintetizan las causales de exención en las tres normas bajo análisis. Los principales cambios, se presentan en la Ley 1861 de 2017, con ocasión del conflicto y el “pos-acuerdo", ya que la Ley 48 de 1993 apenas traduce las mismas causales de la Ley 1 de 1945, ajustándolas a la libertad de cultos y al principio de igualdad entre géneros propugnada por la "nueva" Constitución.

\begin{tabular}{|c|c|c|}
\hline Causales Ley $1^{\text {a }}$ de 1945 & Causales Ley 48 de 1993 & Causales Ley 1861 de 2017 \\
\hline $\begin{array}{l}\text { Los clérigos católicos, seculares y } \\
\text { regulares; los miembros varones de } \\
\text { congregaciones católicas religiosas y } \\
\text { docentes; y los seminaristas o } \\
\text { estudiantes de teología de } \\
\text { establecimientos reconocidos por el } \\
\text { Estado. }\end{array}$ & $\begin{array}{l}\text { Los clérigos y religiosos de acuerdo a } \\
\text { los convenios concordatorios } \\
\text { vigentes. Así mismo, los similares } \\
\text { jerárquicos de otras religiones o } \\
\text { iglesias dedicados permanentemente } \\
\text { al culto. }\end{array}$ & $\begin{array}{l}\text { Los clérigos y religiosos de acuerdo a } \\
\text { los convenios concordatorios } \\
\text { vigentes. Así mismo, los similares } \\
\text { jerárquicos de otras religiones o } \\
\text { iglesias dedicados permanentemente } \\
\text { al culto. }\end{array}$ \\
\hline Los inhábiles absolutos. & $\begin{array}{l}\text { Los limitados físicos y sensoriales } \\
\text { permanentes. }\end{array}$ & \multirow{2}{*}{$\begin{array}{lllr}\text { Las personas en } & \text { situación } & \text { de } \\
\text { discapacidad física, } & \text { psíquica, } & \text { o } \\
\text { sensorial permanente } & & \end{array}$} \\
\hline Los inhábiles relativos permanentes & Los inhábiles relativos y permanentes. & \\
\hline $\begin{array}{l}\text { Los que hubieren sido condenados a } \\
\text { pena que tenga como accesoria la } \\
\text { pérdida de los derechos políticos } \\
\text { mientras no tengan su rehabilitación. }\end{array}$ & $\begin{array}{l}\text { Los condenados a penas que tengan } \\
\text { como accesorias la pérdida de los } \\
\text { derechos políticos mientras no } \\
\text { obtengan su rehabilitación. }\end{array}$ & \\
\hline $\begin{array}{l}\text { El hijo único huérfano de padre con } \\
\text { hermanas solteras que observan buena } \\
\text { conducta o hermanos menores a } \\
\text { quienes sostenga, por no tener a ellos } \\
\text { peculio propio }\end{array}$ & El hi & El hij \\
\hline $\begin{array}{l}\text { El huérfano de padre que atienda con } \\
\text { su trabajo a la subsistencia de sus } \\
\text { hermanos incapaces de ganarse el } \\
\text { sustento. }\end{array}$ & $\begin{array}{l}\text { El huérfano de padre o madre que } \\
\text { atienda con su trabajo a la subsistencia } \\
\text { de sus hermanos incapaces de ganarse } \\
\text { el sustento. }\end{array}$ & $\begin{array}{l}\text { El huérfano de padre o madre que } \\
\text { atienda con su trabajo a la subsistencia } \\
\text { de sus hermanos incapaces de ganarse } \\
\text { el sustento. }\end{array}$ \\
\hline $\begin{array}{l}\text { El hijo de padres incapacitados para } \\
\text { trabajar o que pasen de } 60 \text { años, } \\
\text { cuando estos carezcan de renta, } \\
\text { pensión o medios de subsistencia, y } \\
\text { siempre que dicho hijo vele por ellos }\end{array}$ & $\begin{array}{l}\text { El hijo de padres incapacitados para } \\
\text { trabajar o mayores de } 60 \text { años, cuando } \\
\text { éstos carezcan de renta, pensión o } \\
\text { medios de subsistencia, siempre que } \\
\text { dicho hijo vele por ellos. }\end{array}$ & $\begin{array}{l}\text { El hijo de padres incapacitados para } \\
\text { trabajar o mayores de } 60 \text { años, cuando } \\
\text { éstos carezcan de renta, pensión o } \\
\text { medios de subsistencia, siempre que } \\
\text { dicho hijo vele por ellos. }\end{array}$ \\
\hline
\end{tabular}




\begin{tabular}{|c|c|c|}
\hline $\begin{array}{l}\text { El hermano o hijo de quien haya } \\
\text { muerto prestando sus servicios en las } \\
\text { filas, si su trabajo es indispensable } \\
\text { para la subsistencia de su familia. }\end{array}$ & $\begin{array}{l}\text { Los hijos de oficiales, suboficiales, } \\
\text { agentes y civiles de la Fuerza Pública } \\
\text { que hayan fallecido o adquirido una } \\
\text { inhabilidad absoluta y permanente en } \\
\text { combate o en actos del servicio y por } \\
\text { causas inherentes al mismo } \\
\text { El hermano o hijo de quien haya } \\
\text { muerto o adquirido una inhabilidad } \\
\text { absoluta y permanente en combate, en } \\
\text { actos del servicio o como } \\
\text { consecuencia del mismo, durante la } \\
\text { prestación del servicio militar } \\
\text { obligatorio. }\end{array}$ & $\begin{array}{l}\text { Los hijos de oficiales, suboficiales, } \\
\text { soldados e infantes de Marina } \\
\text { profesionales, agentes, nivel ejecutivo } \\
\text { y de la Fuerza Pública que hayan } \\
\text { fallecido, o que los organismos y } \\
\text { autoridades médico-laborales militar } \\
\text { o de policía hayan declarado su } \\
\text { invalidez, en combate o en actos del } \\
\text { servicio y por causas inherentes al } \\
\text { mismo. } \\
\text { El hermano o hijo de quien haya } \\
\text { muerto o adquirido una inhabilidad } \\
\text { absoluta y permanente en combate, en } \\
\text { actos del servicio o como } \\
\text { consecuencia del mismo, durante la } \\
\text { prestación del servicio militar } \\
\text { obligatorio. }\end{array}$ \\
\hline \multirow[t]{2}{*}{ Los casados que hagan vida conyugal. } & Los casados que hagan vida conyugal. & Los casados que hagan vida conyugal. \\
\hline & $\begin{array}{l}\text { Quienes acrediten la existencia de } \\
\text { unión marital de hecho legalmente } \\
\text { declarada (Jurisprudencia) }\end{array}$ & $\begin{array}{l}\text { Quienes acrediten la existencia de } \\
\text { unión marital de hecho legalmente } \\
\text { declarada }\end{array}$ \\
\hline \multirow[t]{7}{*}{ habidos en el matrimonio. } & El padre de familia (Jurisprudencia) & El padre de familia. \\
\hline & $\begin{array}{l}\text { Los indígenas que residan en su } \\
\text { territorio y conserven su integridad } \\
\text { cultural, social y económica. }\end{array}$ & $\begin{array}{l}\text { Los indígenas que acrediten su } \\
\text { integridad cultural, social y } \\
\text { económica a través de certificación } \\
\text { expedida por el Ministerio del } \\
\text { Interior. }\end{array}$ \\
\hline & & $\begin{array}{l}\text { Los varones colombianos que después } \\
\text { de su inscripción hayan dejado de } \\
\text { tener el componente de sexo } \\
\text { masculino en su registro civil. }\end{array}$ \\
\hline & & $\begin{array}{l}\text { Las víctimas del conflicto armado que } \\
\text { se encuentren inscritas en el Registro } \\
\text { Único de Víctimas (RUV). }\end{array}$ \\
\hline & & $\begin{array}{l}\text { Los ciudadanos incluidos en el } \\
\text { programa de protección a víctimas y } \\
\text { testigos de la Fiscalía General de la } \\
\text { Nación. }\end{array}$ \\
\hline & & $\begin{array}{lll}\begin{array}{l}\text { Los ciudadanos } \\
\text { conciencia. }\end{array} & \text { objetores } & \\
\end{array}$ \\
\hline & & $\begin{array}{l}\text { Los ciudadanos desmovilizados, } \\
\text { previa acreditación de la Agencia } \\
\text { Colombiana para la Reintegración. }\end{array}$ \\
\hline
\end{tabular}

En el cuadro anterior se evidencia claramente, que, a pesar de la existencia de nuevas reglas de orden constitucional, el ajuste en torno a la obligación de la prestación del servicio militar fue mínimo en la Ley 48 de 1993. 
Para efectos de la norma, desde la Ley 48 de 1993, además de los clérigos de la iglesia católica, se incluye a los de otras religiones y comunidades religiosas. Adicionalmente, los seminaristas ya no se encuentran exentos de obligación, si no que serán aplazados para cumplir con la prestación del servicio militar.

En torno a la igualdad de género, se evidencia que los hijos únicos, se encuentran exentos sin la condición que exigía la Ley $1^{a}$ de 1945, en el sentido que además debían ser huérfanos de padre. En el mismo sentido, pasa con la causal referida al huérfano que sostenga a sus hermanos, ya que, a partir de la ley expedida en 1993, aplica la exención, para los huérfanos de padre o madre, esta última situación no prevista en la normativa de 1945.

Como elemento adicional de la Ley 48 de 1993, se incluyen a los indígenas como exentos, siempre y cuando mantengan su integridad cultural, social y económica, lo anterior con miras a dar cumplimiento al artículo 7 de la Constitución Política, en virtud del cual el Estado reconoce y protege la diversidad étnica y cultural de la Nación colombiana.

En la Ley 1861 de 2017, se adoptan las exenciones de la antigua normatividad, pero se amplía en virtud de ciertas garantías para las víctimas del conflicto armado interno y para facilitar la reinserción a la vida civil de actores armados en virtud de procesos de desmovilización. Adicionalmente una causal que jurisprudencialmente ya se había venido desarrollando como lo es la objeción de conciencia, en aplicación del artículo 18 de la Constitución Política y una última que pretende garantizar el libre desarrollo de la personalidad y la libertad sexual, estipulada en el artículo 16 Superior. 


\begin{tabular}{|c|c|c|}
\hline Causales Ley $1^{\text {a }}$ de 1945 & Causales Ley 48 de 1993 & Causales Ley 1861 de 2017 \\
\hline $\begin{array}{l}\text { Ser hermano de quien este prestando } \\
\text { el servicio militar obligatorio. }\end{array}$ & $\begin{array}{l}\text { Ser hermano de quien esté prestando } \\
\text { servicio militar obligatorio }\end{array}$ & $\begin{array}{l}\text { Ser hermano de quien esté prestando } \\
\text { servicio militar obligatorio. }\end{array}$ \\
\hline $\begin{array}{l}\text { Encontrarse detenido previamente por } \\
\text { las autoridades civiles en la época en } \\
\text { que deba ser sorteado. }\end{array}$ & $\begin{array}{l}\text { Encontrarse detenido } \\
\text { preventivamente por las autoridades } \\
\text { civiles en la época en que deba ser } \\
\text { incorporado }\end{array}$ & $\begin{array}{l}\text { Encontrarse cumpliendo medida de } \\
\text { aseguramiento. }\end{array}$ \\
\hline $\begin{array}{l}\text { Resultar inhábil relativo temporal, en } \\
\text { cuyo caso queda aplazado o pendiente } \\
\text { de nuevo reconocimiento hasta el año } \\
\text { siguiente, y si en dicho ano subsistiere } \\
\text { inhabilidad, se le clasificara } \\
\text { definitivamente para el pago de la } \\
\text { cuota de compleción militar. }\end{array}$ & $\begin{array}{l}\text { Resultar inhábil relativo temporal, en } \\
\text { cuyo caso queda pendiente de un } \\
\text { nuevo reconocimiento hasta la } \\
\text { próxima incorporación. Si subsistiere } \\
\text { la inhabilidad, se clasificará para el } \\
\text { pago de la cuota de compensación } \\
\text { militar. }\end{array}$ & \\
\hline $\begin{array}{l}\text { Los estudiantes tienen derecho } \\
\text { aplazamientos anuales sucesivos, } \\
\text { hasta la terminación de los estudios } \\
\text { reglamentarios profesionales, siempre } \\
\text { que no hayan interrumpido en estos, y } \\
\text { a dos años más después de } \\
\text { terminados. }\end{array}$ & \multirow{2}{*}{$\begin{array}{l}\text { A los estudiantes de undécimo grado, } \\
\text { menores de edad que, conforme a la } \\
\text { Ley } 48 \text { de 1993, resultaren elegidos } \\
\text { para prestar dicho servicio, se les } \\
\text { aplazará su incorporación a las filas } \\
\text { hasta el cumplimiento de la referida } \\
\text { edad. Si al acceder a la mayoría de } \\
\text { edad el joven que hubiere aplazado su } \\
\text { servicio militar estuviere matriculado } \\
\text { o admitido en un programa de } \\
\text { pregrado en institución de educación } \\
\text { superior, tendrá la opción de cumplir } \\
\text { inmediatamente su deber o de } \\
\text { aplazarlo para el momento de la } \\
\text { terminación de sus estudios. (Ley } 418 \\
\text { de } 1997 . \text { Art. } 13 \text { ) } \\
\text { El inscrito que esté cursando el último } \\
\text { año de enseñanza media y no } \\
\text { obtuviere el título de bachiller por } \\
\text { pérdida del año. }\end{array}$} & $\begin{array}{l}\text { Estar matriculado o cursando estudios } \\
\text { de educación superior. }\end{array}$ \\
\hline & & $\begin{array}{l}\text { Haber alcanzado la mayoría de edad, } \\
\text { estar aceptado y cursando estudios de } \\
\text { primaria, secundaria o media. El } \\
\text { deber constitucional de prestar el } \\
\text { servicio militar obligatorio nacerá al } \\
\text { momento de obtener el título de } \\
\text { bachiller. }\end{array}$ \\
\hline & $\begin{array}{l}\text { Haber sido aceptado o estar cursando } \\
\text { estudios en establecimientos } \\
\text { reconocidos por las autoridades } \\
\text { eclesiásticas como centros de } \\
\text { preparación de la carrera sacerdotal o } \\
\text { de la vida religiosa. }\end{array}$ & $\begin{array}{l}\text { Haber sido aceptado o estar cursando } \\
\text { estudios en establecimientos } \\
\text { reconocidos como centros de } \\
\text { preparación de la carrera sacerdotal o } \\
\text { de la vida religiosa. }\end{array}$ \\
\hline & $\begin{array}{l}\text { El aspirante a ingresar a las escuelas } \\
\text { de formación de Oficiales, } \\
\text { Suboficiales y Agentes }\end{array}$ & $\begin{array}{l}\text { Haber sido aceptado y estar cursando } \\
\text { como estudiante en las Escuelas de } \\
\text { Formación de Oficiales, Suboficiales } \\
\text { y Nivel Ejecutivo de la Fuerza } \\
\text { Pública. }\end{array}$ \\
\hline & & $\begin{array}{l}\text { Los condenados a penas que } \\
\text { impliquen la pérdida de los derechos } \\
\text { políticos. }\end{array}$ \\
\hline
\end{tabular}


Las causales de aplazamiento, implican que, a pesar de existir la obligación de prestar el servicio militar obligatorio, su cumplimiento efectivo se suspende en el tiempo. Las modificaciones en las causales de aplazamiento han sido básicamente frente a un único aspecto. Este el encontrarse adelantando estudios superiores.

Esta causal desde una perspectiva individual, es totalmente justificada. Si un ciudadano se encuentra adelantando estudios en primaria, media, secundaria o superiores, pareciera justificado que no cumpla con su obligación de prestar el servicio militar, entre otras cosas, por sus derechos constitucionales e inclusive la "utilidad" en términos generales a la sociedad que su preparación representa.

Sin embargo, es necesario analizar dos elementos adicionales. Primero, la edad hasta la cual puede ser incorporado al servicio militar. Segundo, el grupo poblacional que puede acceder a la educación, en especial, a la superior, en nuestro país.

En vigencia de la Ley $1^{\text {a }}$ de 1945 la edad de incorporación se extendía hasta los treinta (30) años; hoy hasta los veinticuatro (24). Si a esto le sumamos, que un estudio de educación superior se cursa como mínimo en cinco (5) años, y que un bachiller en Colombia obtiene ese título entre los diecisiete (17) y los diecinueve (19) años, podríamos decir que es muy poco probable que un varón colombiano que acceda a la educación superior, se incorpore a las filas del servicio militar obligatorio. Ahora bien, al parecer esto nos sería problemático de no ser porque el acceso a la educación superior en Colombia, en un altísimo porcentaje, es posible solo para personas (familias) que tienen los recursos suficientes para costearlo, correspondientes a las clases más acomodadas de la sociedad. 
Lo anterior lo evidencia la Corte Constitucional en múltiples decisiones, entre ellas la Sentencia T-798 de 1998, con ponencia del Magistrado Vladimiro Naranjo Mesa, al manifestar que:

“(...) en las condiciones actuales del país, los cupos en las universidades públicas constituyen bienes escasos, es decir pertenecen a la categoría de recursos respecto de los cuales es superior la demanda por el bien que las existencias de éste. Prueba de ello es el alto número de aspirantes por cada plaza de estudios existente en las universidades públicas”

En resumen, frente a este aspecto, los colombianos deben cumplir con el deber de prestar el servicio militar obligatorio, teniendo en cuenta que desde 1997 los estudiantes de bachillerato menores que hubieren resultado elegidos para prestar el servicio militar, deben aplazar su incorporación hasta tanto cumplan la mayoría de edad. Los seleccionados, que cumplan la mayoría de edad, estando matriculados en un curso de pregrado de un centro de educación superior, pueden aplazar la prestación del servicio militar hasta cuando finalicen los estudios de pregrado u optar por cumplir inmediatamente con el deber de prestar el servicio. A partir de 1999, para los jóvenes que hubieren aplazado el servicio militar hasta finalizar sus estudios tienen el beneficio de reducirlo a seis meses y la posibilidad de homologarlo con los servicios sociales que exigen determinadas profesiones y en el 2001 el beneficio del aplazamiento se extendió a los jóvenes bachilleres mayores quienes al finalizar sus estudios de secundaria pueden, igual que los menores, aplazar el servicio militar hasta cuando finalicen sus estudios de pregrado universitario (Corte Constitucional, Sentencia T774 de 2013. M.P. María Victoria Calle Correa). 
Lo anterior plantea entonces interrogantes como: ¿sí el servicio militar entonces, en virtud del desarrollo legal, en especial de la Ley 1816 de 2017, vigente en la actualidad, desnaturaliza esa obligación, en cabeza de todos los colombianos de prestar el servicio militar? Si a eso se lo suma que una serie de normas, establecen que, en la actualidad, el servicio militar se puede prestar no solo en las Fuerzas Militares, sino en la Policía Nacional (Ley 48 de 1993), en el servicio nacional ambiental (Ley 99 de 1993) y en el Instituto Nacional Penitenciario INPEC (Ley 1816 de 2017), se podría decir que, en parte su carácter y naturaleza dejo de ser militar, para convertirse en un servicio de otra índole. "El servicio militar obligatorio ha suscitado polémicas desde antiguo (SIC), tanto para los dirigentes, como para los propios militares y para la sociedad. Pero al que siempre ha importado de forma ineludible ha sido al joven que le correspondía realizarlo” (Sánchez, 2005, p. 49). 


\section{CAPÍTULO II}

\section{PRINCIPIOS, DERECHOS FUNDAMENTALES Y SERVICIO MILITAR OBLIGATORIO EN LA JURISPRUDENCIA CONSTITUCIONAL}

El presente capítulo pretende identificar y analizar los principios y derechos fundamentales de los individuos que son sujetos pasivos de la obligación derivada del servicio militar obligatorio. Se pretende verificar su nivel de afectación teniendo en cuenta la conceptualización que jurisprudencialmente se tiene de estos principios y derechos, y si la configuración actual de dicho servicio los afecta inconstitucionalmente.

La Constitución Política de 1991, configura a Colombia como un Estado Social de Derecho. Adicionalmente, establece que es un Estado democrático, participativo y pluralista, fundado en la dignidad humana, y que se encuentra al servicio de la comunidad y que tiene la finalidad de garantizar la efectividad de los principios, derechos y deberes consagrados en la Constitución. El Estado colombiano, se encuentra servicio de la comunidad y posee como valores superiores la dignidad humana y la prevalencia de los derechos de las personas" (Vásquez, 2017, p. 18).

La Corte Constitucional colombiana, ha establecido que estos enunciados "no son proclamas retóricas sin efectos normativos, sino que establecen las fórmulas constitucionales básicas, que definen la naturaleza de nuestra organización institucional y delimitan las relaciones que existen entre los ciudadanos y las autoridades" (Corte Constitucional, Sentencia C-251 de 2002. M.P. Eduardo Montealegre Lynett y Clara Inés Vargas Hernández). 
Las primeras normas constitucionales, enmarcan la filosofía política que propia del diseño institucional previsto por la Constitución, razón por la cual, dichas normas contienen los principios esenciales del ordenamiento jurídico y condicionan la acción de todas las autoridades.

Dichos principios constitucionales básicos constituyen un conjunto de "criterios hermenéuticos esenciales para determinar el contenido propio de otras cláusulas constitucionales más particulares, como aquellas que regulan la organización institucional” (Corte Constitucional, Sentencia C-251 de 2002. M.P. Eduardo Montealegre Lynett y Clara Inés Vargas Hernández).

La decisión del constituyente de establecer como obligación de los ciudadanos la de propender al logro y mantenimiento de la paz (Constitución Política, art. 95 \#6) que se concreta en la obligación de todo colombiano de tomar las armas cuando las necesidades públicas lo exijan (Constitución Política, art. 216), tiene impacto y relación directa sobre un claro grupo de principios y derechos constitucionales, que necesariamente deben ser objeto de análisis.

“En una organización social de castas se puede considerar el SMO como una materia propia de los militares y donde el resto de la sociedad no debe inmiscuirse. Sin embargo, si consideramos que lo que ocurre dentro de los cuarteles tiene importantes consecuencias para una sociedad democrática" (Cordero, 1989, p.52) es necesario analizar los principios y derechos más relevantes. 
La dignidad humana, la igualdad, la solidaridad, el interés general el bien común y el libre desarrollo de la personalidad, se encuentran afectan y son afectados significativamente por la precitada obligación de prestar el servicio militar obligatorio.

\subsection{Dignidad Humana}

La dignidad humana es inherente únicamente a la persona humana, es la base de todos los derechos que le son propios. Es anterior al Estado, por lo tanto, no es concesión suya, ni de un gobierno. De acuerdo con la Real Academia de la Lengua Española - RAE, la palabra dignidad proviene del latín dignitas, y significa "calidad de digno", esto es, merecedor de algo; correspondiente, proporcionado al mérito y condición de alguien o algo.

La dignidad humana no es un derecho de los hombres, es el fundamento de los derechos que se conceden al ser humano. Ya lo dejaba ver Kant (1921) cuando afirmaba concretamente:

"(...) Los seres cuya existencia no descansa en nuestra voluntad, sino en la naturaleza, tienen, cuando se trata de seres irracionales, un valor puramente relativo, como medios, y por eso se llaman cosas; en cambio, los seres irracionales se llaman personas porque su naturaleza los distingue ya como fines en sí mismos, esto es, como algo que no puede ser usado como medio y, por tanto, limita, en este sentido, todo capricho (y es objeto de respeto). Estos no son pues, meros fines subjetivos, cuya existencia, como efectos de nuestra acción, tiene un valor para nosotros, sino que son fines objetivos, esto es, realidades cuya existencia es en sí misma, un fin" (p.42). 
La dignidad humana no es otorgada o concedida a los seres humanos por nadie, ésta se debe reconocer en ellos como algo natural propio de su esencia, y es a partir de ese reconocimiento, que el Estado debe concederle y otorgarle tanto derechos como obligaciones.

Para Peces-Barba (2007), la dignidad humana es el paradigma político y jurídico de la modernidad. Se encuentra conformada por cuatro grandes valores: la libertad, la igualdad, la solidaridad y la seguridad jurídica. La concreción de la dignidad humana en la vida social, inseparable de la condición humana, "se plasma en esos cuatro valores, cuyo núcleo esencial lo ocupa la libertad, matizada y perfilada por la igualdad y la solidaridad, en un contexto de seguridad jurídica” (Peces-Barba, 2007, p. 1)

El reconocimiento de la dignidad humana es universal, en el preámbulo de la Carta de las Naciones Unidas se establece que los pueblos de las Naciones Unidas “resueltos (...) a reafirmar la fe en los derechos fundamentales del hombre, en la dignidad y el valor de la persona humana, (...) hemos decidido unir nuestros esfuerzos para realizar estos designios”.

Dentro del ordenamiento jurídico colombiano, el artículo 1 de la Constitución Política dispone en su artículo primero que "Colombia es un Estado social de derecho (...) fundada en el respeto de la dignidad humana".

En la jurisprudencia de la Corte Constitucional Colombiana ha reconocido en diversas oportunidades el concepto de dignidad humana y ha establecido que en el ordenamiento constitucional colombiano tiene una naturaleza triangular. Por una parte, es un principio fundante del ordenamiento jurídico y en este sentido tiene una dimensión axiológica como 
valor constitucional; por otra parte, es un principio constitucional; y finalmente, tiene el carácter de derecho fundamental autónomo (Corte Constitucional, Sentencia T-881 de 2002 M.P. Eduardo Montealegre Lynett).

La Corte ha establecido reiteradamente, que la protección de la Constitución a la dignidad humana como principio y derecho se refiere a tres puntos básicos: la autonomía o posibilidad de diseñar un plan vital y de determinarse según sus características (vivir como se quiere); ciertas condiciones materiales concretas de existencia (vivir bien); y, la intangibilidad de los bienes no patrimoniales, integridad física e integridad moral (vivir sin humillaciones).

La dignidad humana, es un principio fundante del Estado Social, por lo tanto, es el presupuesto esencial de la consagración y efectividad del sistema de derechos y garantías contemplado en la Constitución Política. La dignidad humana "tiene valor absoluto no susceptible de ser limitado bajo ninguna circunstancia, lo que sí ocurre con derechos que necesariamente deben coexistir con otros y admiten variadas restricciones" (Corte Constitucional, Sentencia C-335 de 2008. M.P. Humberto Sierra Porto). Por lo tanto, el respeto a la dignidad humana es una norma jurídica de carácter vinculante para todas las autoridades.

La dignidad humana se establece como un derecho fundamental, de eficacia directa, cuyo reconocimiento general compromete el fundamento político del Estado colombiano. En este sentido, frente a la dignidad humana, la Corte Constitucional en la Sentencia T-499 de 1992 con ponencia del Magistrado Eduardo Cifuentes Muñoz, ha manifestado: 
"El hombre es un fin en sí mismo. Su dignidad depende de la posibilidad de auto determinarse (Art. 16 C.P.). Las autoridades están precisamente instituidas para proteger a toda persona en su vida, entendida en un sentido amplio como "vida plena". La integridad física, psíquica y espiritual, la salud, el mínimo de condiciones materiales necesarias para la existencia digna, son elementos constitutivos de una vida íntegra y presupuesto necesario para la autorrealización individual y social."

El derecho a la dignidad no se configura como una facultad de la persona para adquirir su dignidad, ni para exigirle al Estado que se la otorgue o conceda, ya que la dignidad es un atributo esencial de la persona humana. "El derecho fundamental es a que se le dé un trato que respete plenamente la dignidad del ser humano. Es un derecho que implica tanto obligaciones de no hacer como obligaciones de hacer por parte del Estado" (Corte Constitucional, Sentencia T-702 de 2001. M.P. Marco Gerardo Monroy Cabra).

La debida funcionalidad del derecho a la dignidad humana implica que el ámbito de su protección se extiende a la interdicción de conductas que entrañen la afectación de la dimensión individual y social de la persona. La construcción social de la realidad y la valoración social de ciertas conductas, desde sus niveles particulares de significado, son las que en últimas determinan el ámbito de lo prohibido y de lo que resulta objeto de amparo constitucional y por ende legal.

Frente al servicio militar obligatorio, se evidencia claramente una afectación al derecho a la dignidad humana en sus tres aspectos fundamentales. Por una parte, en relación con la autonomía de las personas para diseñar un plan vital y de determinarse según sus características propias, esto es vivir como se quiere. 
La obligación de prestar el servicio militar, es una clara limitante de este aspecto de la dignidad humana, que ha sido aceptada por la jurisprudencia constitucional, frente a los deberes de los ciudadanos. Sin embargo, si se revisan las condiciones por las cuales se deben tomar las armas, de acuerdo con el artículo 216 Superior, se refieren a las necesidades públicas para defender la independencia nacional y las instituciones. Sin embargo, es necesario tener en cuenta lo manifestado por Vásquez (2017), quien afirma que:

“La prestación del servicio militar no implica por sí un riesgo para la vida en los países que se encuentran en paz, pero sí lo es en aquellos como Colombia, donde se vive un estado de conflicto interno permanente, con características similares a los de una guerra. El servicio militar obligatorio, como precepto constitucional impuesto a los ciudadanos no puede sobreponerse al derecho a la vida” (p. 20)

En este sentido, en un contexto como el colombiano, la imposición de la obligación de prestación al servicio militar podría constituir una violación a este aspecto del derecho fundamental a la dignidad humana. Es claro, que el conscripto no tiene ninguna posibilidad de abstenerse de cumplir su obligación, sacrificando temporalmente, su plan de vida y en ciertos casos hasta la vida misma.

En torno al segundo aspecto esencial de la dignidad humana, es decir el referente a las condiciones materiales concretas de existencia. Sanabria (2012) ha manifestado:

El objeto del derecho fundamental al mínimo vital abarca todas las medidas positivas o negativas constitucionalmente ordenadas con el fin de evitar que la persona se vea 
reducida en su valor intrínseco como ser humano debido a que no cuenta con las condiciones materiales que le permitan llevar una existencia digna” (p. 9-10)

Los conscriptos, quienes a pesar de encontrarse en cumplimiento de una obligación constitucional, no deberían verse empobrecidos en el cumplimiento de dichas obligaciones. Una carga desproporcional de obligaciones, rompería el núcleo esencial del derecho fundamental a la dignidad humana, en términos del mínimo vital. Una "remuneración” que en la actualidad no constituye ni la tercera parte de un salario mínimo, claramente podría generar una vulneración a la dignidad humana en este aspecto tan relevante, si se tiene en cuenta, como se ha manifestado anteriormente, que en Colombia el servicio militar es prestado efectivamente, gran parte de los varones de las clases menos favorecidas.

Finalmente, en relación con el último aspecto relevante de la dignidad humana, la intangibilidad de los bienes no patrimoniales, integridad física e integridad moral, es claro, que, en el desarrollo de las actividades propias del servicio militar obligatorio, se pueden presentar ciertas afectaciones a la integridad física y moral.

Lo anterior se puede entender en el pronunciamiento de la Corte Constitucional en Sentencia C-251 de 2002, en los siguientes términos:

"Si el riesgo para la vida o la integridad no resulta imperioso o necesario, considerada la situación concreta, no ha de propiciarse su exigencia. El deber de arriesgar la vida no es absoluto. En relación con los deberes, únicamente pueden ser exigibles en su integridad cuando el obligado a ellos está en capacidad efectiva de cumplirlos, pues, al igual que los derechos, también tienen sus límites. Deben existir diferentes niveles en 
los cuales se puede cumplir con la obligación constitucional de tomar las armas teniendo en cuenta el entrenamiento, disposición y aptitudes de quien va a defender la independencia, soberanía e integridad institucional. Quienes prestan el servicio militar obligatorio en su condición de bachilleres o campesinos, si bien están obligados a tomar las armas y reciben para ello una formación mínima, si su preparación y adiestramiento en el aspecto militar y de defensa personal no alcanza niveles evidentes de proporcionalidad frente al peligro que afrontan"

En conclusión, podría decirse que en las condiciones en las cuales se presta efectivamente el servicio militar obligatorio en Colombia, se podrían evidenciar afectaciones al derecho a la dignidad humana en sus tres aspectos fundamentales.

\subsection{Igualdad}

La igualdad de todos ante la ley ha sido uno de los logros más importantes de las sociedades modernas hacia la plena realización del Estado social de derecho. Sin embargo, no tendría ningún significado, si la igualdad que se proclama fuera de carácter formal y no material, por cuanto ésta última es necesaria para lograr una verdadera equiparación entre las personas que, dadas sus condiciones (sociales, económicas, físicas, etc.) no cuentan con medios reales y eficaces para ser tratadas como iguales.

Torres (2009), relaciona la idea de igualdad con la justicia. Se reconoce al otro como igual, es decir, merecedor del mismo trato que cada individuo considera merecer. "Toda persona es igualmente digna que las otras y por lo tanto debe tener los mismos derechos 
frente al Estado. Aquí aparece una noción de justicia que corre en paralelo con el principio de igualdad” (p.1).

En este sentido la Corte Constitucional en Sentencia C-932 de 2007 ha manifestado lo siguiente:

"El cambio de concepción de la igualdad formal a la igualdad material, propio del Estado Social de Derecho, según el cual las autoridades públicas no sólo protegen el derecho mediante la abstención sino también y, en algunas oportunidades en forma obligatoria, mediante la intervención activa en esferas específicas, generó decisiones públicas proteccionistas de grupos de personas que han sido tradicionalmente marginados o discriminados por razones diversas"

Así las cosas, la aplicación efectiva y real del principio de igualdad en el constitucionalismo moderno exige del Estado su intervención, para evitar que los actos de los agentes públicos y los particulares sean discriminatorios, y para hacer exigibles a estos, tratos favorables en beneficio de personas que se encuentran en situación de debilidad manifiesta.

El reconocimiento de la igualdad, al igual que el de la dignidad humana es universal, como se puede evidenciar claramente en el preámbulo de la Carta de las Naciones Unidas, la cual establece que los pueblos de las Naciones Unidas "resueltos (...) a reafirmar la fe en los derechos fundamentales del hombre, (.. en la igualdad de derechos de hombres y mujeres (...) hemos decidido unir nuestros esfuerzos para realizar estos designios”. 
Por su parte, en el derecho colombiano la igualdad ante la ley se encuentra consagrada en la Constitución Política en el preámbulo que señala:

"El pueblo de Colombia, en ejercicio de su poder soberano... con el fin de fortalecer la unidad de la Nación y asegurar a sus integrantes la vida, la convivencia, el trabajo, la justicia, la igualdad, el conocimiento, la libertad y la paz... decreta, sanciona y promulga la siguiente Constitución Política de Colombia”.

Así mismo, el artículo $5^{\circ}$ de la Carta establece que "El Estado reconoce, sin discriminación alguna, la primacía de los derechos inalienables de la persona”.

El artículo 13 de la Constitución Nacional confiere a la igualdad el carácter de derecho constitucional fundamental, pues establece lo siguiente:

“Todas las personas nacen libres e iguales ante la ley, recibirán la misma protección y trato de las autoridades y gozarán de los mismos derechos, libertades y oportunidades sin ninguna discriminación por razones de sexo, raza, origen nacional o familiar, lengua, religión, opinión política o filosófica. El Estado promoverá las condiciones para que la igualdad sea real y efectiva y adoptará medidas en favor de grupos discriminados o marginados. El Estado protegerá especialmente a aquellas personas que, por su condición económica, física o mental, se encuentren en circunstancia de debilidad manifiesta y sancionará los abusos o maltratos que contra ellas se cometan". 
La igualdad que proclama el Estado social es al mismo tiempo valor, principio y derecho fundamental, como también pilar de la organización política, en cuanto hace parte de la concepción dignificante del ser humano.

Para explicar el alcance del artículo 13 de la Constitución Política y el principio de igualdad allí previsto, la Corte Constitucional ha expuesto que la igualdad contiene seis elementos. Primero, un principio general: todas las personas nacen libres e iguales ante la ley y recibirán la misma protección y trato de las autoridades. Segundo, la prohibición de discriminaciones: este elemento pretende que no se otorguen privilegios, se niegue el acceso a un beneficio, o se restrinja del ejercicio de un derecho a un determinado individuo o grupo de personas de manera arbitraria e injustificada, por razón de su sexo, raza, origen nacional o familiar, sus opiniones o convicciones expresadas en el ejercicio de libertades protegidas constitucionalmente como la libertad de expresión, de cultos o de conciencia. Tercero, el deber del Estado de promover condiciones para lograr la igualdad real y efectiva. Cuarto, la posibilidad de conceder ventajas a grupos disminuidos o marginados. Quinto, una especial protección en favor de aquellas personas que por su condición económica, física o mental se encuentren en circunstancias de debilidad manifiesta. Sexto, la sanción de abusos y maltratos que se cometan contra personas en circunstancias de debilidad manifiesta (Corte Constitucional, Sentencia T-591 de 1992. M.P. Jaime Sanin Greiffenstein).

La Carta Magna reconoce la igualdad ante la ley a todas las personas, consagra ante las autoridades los derechos a la igualdad de protección y a la igualdad de trato, y reconoce a toda persona el goce de los mismos derechos, libertades y oportunidades, sin discriminación 
con base en criterios de sexo, raza, origen nacional o familiar, lengua, religión, opinión política o filosófica.

Se trata entonces, de tres dimensiones diferentes del principio de igualdad: la igualdad ante la ley, la igualdad de trato y la igualdad de protección.

La igualdad ante la ley, en virtud la cual la ley debe ser aplicada de la misma forma a todas las personas., garantiza que la ley se aplique por igual, pero no que la ley en sí misma trate igual a todas las personas. La igualdad ante la ley obliga entonces, a que ésta sea aplicada "de modo igual a todos aquellos que se encuentran en la misma situación, sin que el operador pueda establecer diferencia alguna en razón de las personas, o de circunstancias que no sean precisamente las presentes en las normas" (Rubio, 1995, p.2)

Por ello es necesaria la segunda dimensión, la igualdad de trato, que garantiza a todas las personas que la ley que se va a aplicar no regule de forma diferente la situación de personas que deberían ser tratadas igual, o lo contrario, que regule de forma igual la situación de personas que deben ser tratadas diferente.

La igualdad de protección asegura efectivamente, gozar de los mismos derechos, libertades y oportunidades. Esta dimensión del principio de igualdad, es sustantiva y positiva. Sustantiva porque parte de la situación en que se encuentran los grupos a comparar para determinar si el tipo de protección que reciben y el grado en que se les otorga es desigual, cuando debería ser igual. Es positiva porque en caso de presentarse una desigualdad injustificada en razones objetivas relativas al goce efectivo de derechos, lo que procede es asegurar que el Estado adopte acciones para garantizar la igual protección. 
Como se ha podido establecer, el ordenamiento jurídico colombiano ha establecido la obligación "formal" de todos los colombianos de tomar las armas cuando las necesidades públicas lo exijan (Constitución Política, art. 216). Sin embargo, el régimen del servicio militar obligatorio podría afectar el derecho a la igualdad material, frente a dos situaciones como mínimo. Primero, frente a la voluntariedad del servicio militar para las mujeres. Segundo, frente a las exenciones y aplazamientos, en especial la relacionada con encontrarse adelantando estudios de educación superior.

Frente al primer aspecto, es evidente que, en el mundo, la incorporación de la mujer a las Fuerzas Armadas, en especial al servicio militar, es una realidad que ha venido a fracturar un modelo de organización social tradicional que asignaba al hombre el rol de guerrero y a la mujer el de madre, respecto de las tres las funciones básicas atribuidas a la mujer en la sociedad tradicional. "Las tres famosas " $k$ " del Kaiser Guillermo ll: Kinder Kirche y Küche: niños, iglesia y cocina” (Fernández, 2000, p. 21).

En España, por ejemplo, en 1989 se estableció la incorporación de la mujer a las Fuerzas Armadas. Lo anterior constituía un intento por adecuarse a una situación que, en los países de la Alianza Atlántica era una realidad de años atrás. Así las cosas, “en líneas generales, la posición de las mujeres en la carrera militar española es de una casi plena igualdad con el hombre” (Lence, 1995, p. 56).

En el caso colombiano, la jurisprudencia constitucional ha establecido que la igualdad de trato o igualdad en la ley, una de las tres dimensiones del derecho a la igualdad a las que se hizo referencia anteriormente, "consiste en proteger en mayor medida los intereses de 
ciertas personas, esto es, un deber especial del Estado de otorgar un trato preferente a grupos discriminados o marginados y de protección especial a grupos determinados" (Corte Constitucional, Sentencia C-540 de 2008. M.P. Humberto Antonio Sierra Porto), como es el caso de la mujer.

En ese orden de ideas, siguiendo la tradición jurisprudencial, podría entonces entenderse que el servicio militar obligatorio para las mujeres no constituye una vulneración al derecho a la igualdad, por los argumentos que constantemente ha utilizado dicho tribunal para el trato diferenciado.

En torno al segundo aspecto que puede vulnerar el derecho a la igualdad, esto es, frente a las exenciones y aplazamientos, en especial la relacionada con encontrarse adelantando estudios de educación superior, es necesario tener en cuenta la decisión de la Corte Constitucional en Sentencia C-511 de 1994, en la que declaró la exequibilidad del artículo 13 de la Ley 48 de 1993, en la que se establecía un término menor de prestación del servicio militar para los soldados bachilleres, indicando que no había inequidades en el trato diferenciado de unos y otro, sino más bien un "trato diferencial propio de las distintas situaciones objeto de regulación por la ley”. La Corte Constitucional se pronunció en los siguientes términos:

“A nadie escapa el sentido de la distinción entre bachiller y no bachiller, pues, condiciones materiales bien marcadas distinguen por el grado de capacitación intelectual a los unos frente a los otros; grado que, es el resultado de un esfuerzo, en países como el nuestro, por mejorar los niveles de desempeño de las personas en los distintos campos de la cultura. Entonces, a juicio del legislador, imponer un plazo mayor 
de 12 meses a los bachilleres llamados a desempeñar labores y tareas en la vida social, en este conjunto normativo de la economía, no debe confundirse, con un trato privilegiado” (Corte Constitucional, Sentencia C-511 de 1994. M.P. Fabio Morón Díaz)

En este punto es supremamente importante tener en cuenta que, en la misma decisión, la Corte ha manifestado, que el derecho a la igualdad "no puede entenderse, desconociendo la realidad, como la obligación pública y particular de dar un tratamiento homogéneo a los distintos estratos sociales" (Corte Constitucional, Sentencia C-511 de 1994. M.P. Fabio Morón Díaz.

Con fundamento en lo anterior un ejercicio prospectivo implicaría entender que la Corte Constitucional, entiende que el esfuerzo de una persona por superarse a través del estudio es suficiente argumento para que el legislador le dé un trato diferenciado frente a su obligación concreta de prestar activamente el servicio militar.

Así las cosas, de acuerdo con los lineamientos de la Corte Constitucional, una exención diseñada, principalmente para los estudiantes de programas de educación superior no violaría la Constitución, a pesar que, a estos acceden en su mayoría, personas de las clases sociales más acomodadas. En palabras de Rodríguez (2016):

\footnotetext{
"Se puede colegir que el eje medular del Estado Social de Derecho en Colombia, fundado en la dignidad humana, vulnera el ordenamiento jurídico tanto en la norma de normas, como en el bloque de constitucionalidad que la componen; ante discriminaciones fundamentadas única y exclusivamente en condiciones sociales y educativas para los conscriptos" (p.13).
} 


\subsection{Libre desarrollo de la personalidad}

El derecho al libre desarrollo de la personalidad, se encuentra establecido en el artículo 16 de la Constitución Política, en los siguientes términos: “todas las personas tienen derecho al libre desarrollo de su personalidad sin más limitaciones que las que imponen los derechos de los demás y el orden jurídico”.

Este derecho se ha entendido como "la facultad que tienen los individuos de realizar su proyecto de vida conforme a sus valores, intereses, creencias y convicciones, sin más límites que los derechos de los demás y el orden jurídico" (Corte Constitucional, Sentencia T-077 de 2016. M.P. Jorge Iván Palacio Palacio).

El libre desarrollo de la personalidad, se enmarca dentro de un contexto jurídico, a pesar de ser un concepto en donde confluyen factores extrajurídicos como lo son la ética y la psicología. Este derecho fundamental se estableció por cuenta del Tribunal Constitucional Federal Alemán en 1957 con el caso Elfe donde se reconoció el derecho a desarrollar libremente la personalidad como libertad principal o libertad general de acción, estableciendo que este derecho es el ámbito último intangible de la libertad humana y que la garantía de la libertad general de acción se presenta como una extensión de la protección más allá de este ámbito, amparándose de este modo todas las libertades y derechos fundamentales de la persona humana, estén o no enumeradas en el catálogo de derechos constitucionales fundamentales (Tribunal Constitucional Federal Alemán, Sentencia de 16 de enero de1957) 
En Colombia, la Corte Constitucional, ha concretado dicho derecho, en múltiples decisiones, entre las que se encuentra la Sentencia T-429 de 1994. En esta decisión, el tribunal manifestó que el derecho al libre desarrollo de la personalidad:

“implica el reconocimiento de la aptitud fisica y moral que tienen todas las personas a realizarse individual y autónomamente, sin imposiciones o forzamientos de ninguna clase y sin controles injustificados o impedimentos por parte de los demás, incluido el Estado, a menos que exista una obligación legal o contractual legítima o un deber social o cuando las respectivas acciones atenten contra los derechos de las demás personas o quebranten el orden público o contraríen una disposición jurídica que tenga la virtualidad de poder limitar válidamente el ejercicio del derecho aludido”.

El núcleo esencial del derecho al libre desarrollo de la personalidad, hace referencia al conjunto de decisiones que un individuo "toma de manera autónoma durante su existencia, determinando su modelo de vida y la visión de su dignidad como persona" (Corte Constitucional, Sentencia C-481 de 1998. M.P. Alejandro Martínez Caballero).

El Estado Social de Derecho proclamado en la Constitución Política de 1991, se ha fundamentado, como se ha manifestado, en la dignidad humana, que implica la autonomía de la persona para definir, sin interferencias ajenas, "el sentido de su propia existencia y el significado que atribuye a la vida y al universo, pues tales determinaciones constituyen la base misma de lo que significa ser una persona humana" (Corte Constitucional, Sentencia C-481 de 1998. M.P. Alejandro Martínez Caballero). 
La Corte Constitucional ha reconocido en el libre desarrollo de la personalidad "un contenido sustancial que se nutre del concepto de persona sobre el que se erige la Constitución”, en el entendido que la Carta Magna exhibe la defensa de la condición ética de la persona humana, "que la hace instancia suprema e irreductible de las decisiones que directamente le incumben en cuanto que gracias a ellas determina y orienta su propio destino como sujeto autónomo, responsable y diferenciado” (Corte Constitucional, Sentencia C-221 de 1994. M.P. Carlos Gaviria Díaz).

Como se manifestó, si el derecho al libre desarrollo de la personalidad desde una perspectiva individual, se manifiesta en la "definición consciente y responsable que cada persona puede hacer frente a sus propias opciones de vida y a su plan como ser humano”, a lo que le corresponde un aspecto colectivo, que corresponde al respeto de las decisiones individuales tomados por los demás miembros de la sociedad (Corte Constitucional, Sentencia T-903 de 2003. M.P. Rodrigo Escobar Gil), este derecho se ve afectado frente a la obligación de prestar el servicio militar obligatorio.

Es evidente que la naturaleza de lo obligatorio y la rigidez en los procesos y actividades al interior de las Fuerzas Armadas, una vez se han incorporado a los conscriptos, implica una seria afectación a dicho derecho. Si algo es necesario en las filas de las Fuerzas Armadas, especialmente en las Militares, es la obligación de cumplir con la rigidez doctrina militar, que incluye, valores, principios, reglas, etc., lo que se evidencia en las diferentes normas disciplinarias, laborales y penales propias, de los miembros del Ejército, la Armada, la Fuerza Aérea y la Policía Nacional. 
Lo anterior no sería problemático si el ingreso a las filas fuera voluntario y no obligatorio como evidentemente lo es.

Frente al servicio militar obligatorio, la Corte Constitucional ha protegido el libre desarrollo de personalidad, principalmente, frente a dos temas. Primero en torno a la objeción de conciencia. Segundo, frente al derecho a la educación.

En relación con la objeción de conciencia, se podría afirmar que esta consiste en la negativa a cumplir un mandato de la autoridad o una norma jurídica, invocando la existencia, en el fuero de la conciencia, de un imperativo que prohíbe dicho cumplimiento. Concretamente, en palabras de Jean-Pierre Cattelain, "la objeción de conciencia consiste «en oponer la ley de la conciencia a la ley oficial”. Se trata, en síntesis, de negarse a cumplir un deber por dar preeminencia a la ley moral sobre la ley jurídica. Como se puede evidenciar, la objeción de conciencia contiene dos elementos básicos. Primero, la negativa a cumplir un deber jurídico impuesto por una norma o por una autoridad. Segundo, el concreto fundamento de dicha negativa, que debe venir impuesta por un imperativo de la propia conciencia. (Oliver, 1996, p. 2-3).

De acuerdo con la Corte Constitucional, a objeción de conciencia al servicio militar obligatorio es un derecho fundamental y una causal de exención a la prestación de dicho servicio, que tienen raigambre constitucional y, por ende, supra legal, en cabeza de quien "demuestre que por convicciones personales profundas, sinceras, continuas y exteriorizadas, tiene razones de conciencia que le impiden ejercer la actividad militar" (Corte Constitucional, Sentencia T-455 de 2014. M.P. Luis Ernesto Vargas Silva). 
Lo anterior fue recogido por la Ley 1816 de 2017, en el artículo 12, ordinal n, estableciendo que los objetores de conciencia estaban exentos de prestar el servicio militar obligatorio y estableciendo un procedimiento para garantizar dicho derecho.

En torno al derecho a la educación en contraposición con el servicio militar obligatorio, se podría manifestar que en virtud del artículo 67 Superior, la educación debe ser objeto de protección por parte del Estado, independientemente de su naturaleza formal, no formal o informal; la modalidad o la institución educativa en la que se lleve a cabo. Por lo tanto, la protección integral del derecho a la educación implica que no debe haber discriminación alguna en tanto su garantía permite el reconocimiento de otros derechos constitucionales fundamentales (Corte Constitucional, Sentencia T-774 de 2013).

Concretamente, frente a la educación y el servicio militar obligatorio, el Tribunal Constitucional ha manifestado:

“La Constitución Política es diáfana al consagrar y proteger la educación, sin importar nivel, modalidad o claustro, como un derecho superior, por lo que mal puede el Ejército Nacional condicionar el reconocimiento de una prerrogativa que para el caso comprende el aplazamiento en la prestación del servicio militar, a que la persona se encuentre matriculada estrictamente en una institución de educación formal, como lo serían los centros universitarios, desestimando los establecimientos educativos que el mismo Estado "ha autorizado mediante actos administrativos para que ofrezcan programas educativos a la sociedad, facilitando el acceso a las personas, acorde, desde luego, a su vocación y condiciones socioeconómicas" (Corte Constitucional, Sentencia T-774 de 2013). 
Frente a la protección que ha otorgado tradicionalmente la Corte frente a la objeción de conciencia no es de manera alguna problemática. Hipotéticamente se debería predicar los mismo en relación con la protección que ha hecho este Tribunal en torno al derecho a la educación, de no ser, por que como se ha manifestado reiterativamente, quienes acceden a dicho servicio público son en su mayoría privilegiados en términos socio económicos.

De lo expuesto anteriormente, se podría llegar a la conclusión, de que, en el mundo moderno, "en los valores civiles existe una preferencia por las acciones amparadas en la voluntariedad frente a la obligatoriedad, y la diversidad y heterogeneidad gana puntos frente a la homogeneidad en la mayoría de los terrenos” (Sánchez, 2005).

Así las cosas, es evidente que gran parte de los que prestan efectivamente el servicio militar obligatorio se ven afectados significativamente en sus libertades esenciales. Esto sin tener en cuenta, la nueva regla incorporada por el ordinal e artículo 15 de la Ley 1816 de 2017, en la que se incluyó que la prestación del servicio militar, se podría llevar a cabo como auxiliar del cuerpo de custodia en el Instituto Nacional Penitenciario - INPEC. En este sentido, obligar a ciudadanos a ejercer la custodia de los reclusos del país, no parece otra cosa que un exceso del Estado frente a las obligaciones de ciertos ciudadanos, en relación con sus derechos a tomar decisiones, entre otras las de relacionarse libremente con quien ellos deseen. Ejercer la custodia de reclusos, con los que se relacionen, en virtud de las actividades adelantadas, podría implicar un peligro para sus vidas, aun mayor que para quienes prestan el servicio militar obligatorio, ya que ha sido constante los asesinatos y amenazas contra el Cuerpo de Vigilancia y Custodia del INPEC. 


\subsection{Solidaridad}

De las normas constitucionales, en especial el artículo 1 Superior, se colige que el principio de la solidaridad se entiende como un deber en cabeza del Estado y de todos los colombianos. Es un principio de doble vía, se erige de lo público hacia lo privado, y luego en el sentido contrario. Concretamente, "el deber de solidaridad se configura como un derecho-deber cuya exigencia puede hacerse de manera directa en especial en los casos en que de su cumplimiento dependa el respeto de derechos fundamentales de las personas" (Corte Constitucional, Sentencia T-1095 de 2005. M.P. Clara Inés Vargas Hernández).

Con esa lógica, el deber de solidaridad en un Estado Social de Derecho, es inherente a su misma existencia y en relación directa con el cumplimiento de sus fines esenciales. Por su parte, cuando se encuentra en cabeza de los particulares, el deber de solidaridad es exigible cuando sea determinado por el legislador. En este sentido la Corte Constitucional se ha pronunciado en los siguientes términos:

"La solidaridad responde en el ser humano a móviles para su ocurrencia. No es de esperar que ella siempre despunte por generación espontánea, dado que, si bien la espontaneidad para dar de sí a quien lo necesita es una importante fuente de solidaridad, es de reconocer que ésta puede ser válidamente inducida, promocionada, patrocinada, premiada y estimulada por el Estado en orden a la materialización y preservación de determinados bienes jurídicos de especial connotación social" (Corte Constitucional, Sentencia C-237 de 1997. M.P. Carlos Gaviria Díaz) 
La solidaridad es un principio constitucional fundamental, que le imprime ciertos parámetros de conducta social a los particulares, en ámbitos muy específicos de sus relaciones sociales, principalmente, pero de manera exclusiva en las relaciones familiares.

Álvarez (1984) considera que la simple proclamación del principio de solidaridad constituye el camino adecuado para profundizar en una línea de interdependencia y participación de funciones, en el entendido que "el principio de solidaridad debe ser concebido como un cauce de cooperación y de participación, que tiene un contenido incompleto que debe ser rellenado por los poderes públicos mediante la articulación de las técnicas necesarias” (pág. 857).

Según la jurisprudencia constitucional, en el Estado Social de Derecho, “el principio de solidaridad cumple la función de corregir sistemáticamente algunos de los efectos nocivos que tienen las estructuras sociales y económicas sobre la convivencia política a largo plazo” (Corte Constitucional, Sentencia C-520 de 2003. M.P. Rodrigo Escobar Gil).

Sin embargo, es necesario tener presente que la solidaridad exigible a los particulares, "no es un instrumento necesario para garantizar la convivencia política, independientemente del modelo de Estado" (Corte Constitucional, Sentencia C-459 de 2005. M.P. Jaime Araujo Rentería). La solidaridad establecida en la Constitución Política de 1991, es apropiada en el ordenamiento colombiano en virtud de la fórmula de Estado Social de Derecho, como instrumento normativo propio de dicho tipo de Estado. 
Así mismo, la Corte Constitucional ha manifestado que la solidaridad "es valor constitucional que en cuanto fundamento de la organización política presenta una triple dimensión”. Primero, se considera como una pauta de comportamiento conforme a la cual deben obrar las personas en determinadas ocasiones. Segundo, se entiende como un criterio de interpretación en el análisis de las acciones u omisiones de los particulares que vulneren o amenacen los derechos fundamentales. Tercero, la solidaridad constituye un límite a los derechos propios (Corte Constitucional, Sentencia C-459 de 2005. M.P. Jaime Araujo Rentería).

Lo anterior se fundamenta en el hecho de la Constitución pretende garantizar la pluralidad de pensamiento y el respeto a la diferencia entre los ciudadanos, derivada del artículo 13 Superior, lo cual rige los fines del Estado y las acciones de las instituciones públicas y de las relaciones entre los particulares y las autoridades públicas.

Así las cosas, "el deber de solidaridad del Estado ha de ser entendido como derivación de su carácter social y de la adopción de la dignidad humana como principio fundante del mismo". En virtud de lo anterior, el Estado tiene la obligación de garantizar condiciones mínimas de vida digna a todas las personas, razón por la cual, debe prestar asistencia y protección a quienes se encuentren en circunstancias de inferioridad. Para ello, tiene diversos mecanismos directos o indirectos. Directos, adoptando medidas en favor de aquellas personas que se encuentren en circunstancias de debilidad manifiesta indirecta, por razones económicas, físicas o mentales; indirectos, a través de la inversión en el gasto social (Corte Constitucional, Sentencia C-237 de 1997. M.P. Carlos Gaviria Díaz). 
Sin embargo, es preciso tener en cuenta lo siguiente, según lo manifestado por el Tribunal Constitucional en Sentencia T-1206 de 2001:

"Es claro que el Estado no tiene el carácter de benefactor, del cual dependan las personas, pues su función no se concreta en la caridad, sino en la promoción de las capacidades de los individuos, con el objeto de que cada quien pueda lograr, por sí mismo, la satisfacción de sus propias aspiraciones. Pero, el deber de solidaridad no se limita al Estado: corresponde también a los particulares, de quienes dicho deber es exigible en los términos de la ley, y de manera excepcional, sin mediación legislativa, cuando su desconocimiento comporta la violación de un derecho fundamental"

El deber de solidaridad no implica la obligación de los particulares de asumir indiscriminadamente cualquier tipo de riesgo que comporte una amenaza para sus derechos, pues ello significaría que el Estado está abdicando de su función de garantizar la eficacia de tales derechos y equivaldría a afirmar que es imposible controlar las medidas administrativas por la sola legitimidad de las finalidades que persiguen. Por el contrario, "el sometimiento del Estado al ordenamiento jurídico supone también un control sobre los mecanismos por medio de los cuales éste desarrolla los objetivos constitucionales" (Corte Constitucional, Sentencia T-1206 de 2001. M.P. Rodrigo Escobar Gil).

Contrario a lo anterior, la jurisprudencia constitucional ha considerado que el servicio militar, en la Constitución Colombiana, específicamente, en el artículo 216, se encuentra concebido como una forma de responsabilidad social que se conserva entre la sociedad civil y el Estado. 
Para lo Corte Constitucional, es un mecanismo de participación solidaria, ya que, en la Sentencia T-218 de 2010, lo entiende de la siguiente manera:

"la posibilidad de que el ciudadano participe en la tarea de asegurar la convivencia pacífica de los habitantes del territorio colombiano, sin que ello propiamente implique una vulneración a los derechos de los particulares, en la medida en que su esencia materializa el ejercicio de la solidaridad ciudadana en un servicio especial $e$ impostergable que requiere, en todos los tiempos, la sociedad"

La problemática que surge del servicio militar obligatorio y la solidaridad como se ha descrito anteriormente, se trata de determinar los alcances del deber de solidaridad en cabeza de unos pocos, marginados, en condiciones de inferioridad, que se ven obligados a prestar el servicio militar obligatorio, ya que no poseen los recursos económicos para iniciar o continuar estudios y poder ser objeto de discriminación legal positiva, en el entendido que se privilegia su derecho a la educación frente a la obligación de servir militarmente a la patria en los términos de la Ley. Por su parte, aunque existe la obligación de una compensación económica para quienes no prestan el servicio militar obligatoria, poseen recursos suficientes para poder cubrirla, además de poder acceder a la educación superior.

En ese entendido, el concepto de solidaridad no se reduce a su contenido económico, como distribución equitativa de la riqueza. La solidaridad es la consecuencia práctica de un pasado común, construido con los aportes de todos, y exigencia de una empresa colectiva proyectada hacia el futuro. Pero la noción pluridimensional del concepto, además de un marcado sentido económico, la solidaridad posee un alcance jurídico y político (Fernández, 2012). Así las cosas, el deber tendría que estar en cabeza de todos con pocas excepciones. 


\subsection{Interés general y bien común}

Hegel (1968) sostenía que el fin del Estado es el interés general como tal, y que, de lo anterior, como sustancia, radica la conservación de los intereses particulares. Lo anterior constituye en primera medida, "su realidad abstracta o sustancialidad"; pero ella, además, "su necesidad en cuanto se dirime en las diferencias conceptuales de su actividad, las que por medio de aquella sustancialidad son igualmente estables determinaciones reales, son poderes". Sin embargo, dicha sustancialidad, "es el Espíritu conocedor de sí y amante de sí, en cuanto transcurrido a través de la forma de la cultura” (p.220).

El principio de prevalencia del interés general permite preferir la consecución de objetivos comunes sobre intereses particulares, siempre y cuando el interés particular no se encuentre amparado por un derecho constitucional. Así las cosas, es necesario entender que el respeto de esos derechos constitucionales es un componente integrante del interés general.

La Corte Constitucional ha establecido que la única forma como los derechos constitucionales pueden tener una eficacia normativa verdadera es reconociendo que ellos, como lo señala la doctrina y lo ha establecido la jurisprudencia de la Corporación, "son verdaderas cartas de triunfo contra el bienestar colectivo", y por ende no pueden "ser disueltos en un cálculo utilitario sobre el bienestar colectivo, ni pueden estar sometidos al criterio de las mayorías, ya que esos derechos son precisamente limitaciones al principio de mayoría y a las políticas destinadas a satisfacer el bienestar colectivo" (Corte Constitucional, Sentencia C-251 de 2002. M.P. Eduardo Montealegre Lynett y Clara Inés Vargas Hernández). 
De lo anterior se deriva que la validez de un derecho constitucional, no debe someterse al criterio de la mayoría, y como consecuencia, tampoco su compatibilidad con los objetivos de interés general. De lo contrario, implicaría "quitarle toda su eficacia específica puesto que, en una gran medida, los derechos constitucionales fundamentales son las promesas que formulan las mayorías a las minorías" (Corte Constitucional, Sentencia C251 de 2002. M.P. Eduardo Montealegre Lynett y Clara Inés Vargas Hernández).

El concepto de interés general tiene una naturaleza jurídicamente abstracta e indeterminada, lo que ha conducido, a que los Estados, con Constituciones de corte liberal, como la de nuestro Estado Social de Derecho, requieran armonizar dicho precepto con de los derechos individuales y los conceptos del pluralismo y la participación.

En torno a la cláusula de prevalencia del interés general sobre el interés particular, estatuida en el artículo $1^{\circ}$ Superior, "la Corte Constitucional ha rechazado su invocación a priori como razón de Estado para justificar una conducta irracional, la protección injustificada de un interés oculto o la vulneración de los derechos de las personas" (Corte Constitucional, Sentencia C-053 de 2001. M.P. Cristina Pardo Schlesinger).

Así las cosas, cada vez que se invoque la existencia de un interés general, esta debe verificarse en cada caso concreto. Además, una vez determinada la existencia efectiva de un interés general, que fundamente una determinada acción del Estado, no implica que la cláusula de prevalencia del interés general sobre el particular sea absoluta, ni susceptible de aplicación inmediata. 
La aplicación de dicha cláusula debe entenderse condicionada a que la invocación de tal interés "esté realmente dirigida a la obtención de los objetivos constitucionales y, a la vez, mediatizada por los principios de razonabilidad y proporcionalidad, en aras de conciliarla con los intereses particulares, principalmente, con los derechos fundamentales” (Corte Constitucional, Sentencia C-722 de 2007. M.P. Clara Inés Vargas Hernández).

Por ello, para su aplicación es necesario armonizar el interés general con los derechos de los particulares y, en caso de no ser posible, se pondere teniendo en cuenta la jerarquía de valores propia de la Constitución. Así lo ha entendido la Corte Constitucional:

"Ante todo es necesario aclarar que el concepto de interés general, como todas las normas constitucionales que consagran valores generales y abstractos, no siempre puede ser aplicado de manera directa a los hechos. La Constitución establece la prevalencia del interés general en su artículo primero, pero también establece la protección de numerosos valores relacionados con intereses particulares, como es el caso de los derechos de la mujer, del niño, de los débiles, etc. El Estado Social de Derecho y la democracia participativa se han ido construyendo bajo la idea de que el reino de la generalidad no sólo no puede ser llevado a la práctica en todas las circunstancias, sino que, además, ello no siempre es deseable; la idea del respeto a la diversidad, al reconocimiento de las necesidades específicas de grupos sociales diferenciados por razones de cultura, localización, edad, sexo, trabajo, etc., ha sido un elemento esencial para la determinación de los derechos sociales económicos y culturales y en términos generales, para el logro de la justicia” (Corte Constitucional, Sentencia T-428 de 1992. M.P. Ciro Angarita Barón). 
En ese orden de ideas, frente al servicio militar obligatorio, la cláusula del artículo 216 Superior, en torno a que los colombianos están obligados a tomar las armas cuando las necesidades públicas lo exijan, ha otorgado cierto grado de discrecionalidad al legislador, quien sigue considerando que las necesidades históricas y actuales ameritan dicha obligación.

Esta discrecionalidad se traslada a las autoridades militares de reclutamiento, quienes, deciden, arbitrariamente, entre otros asuntos, el número de efectivos necesarios para conformar cada contingente, la asignación de los conscriptos a las unidades y las actividades y labores que estos desempeñan. Es de anotar que las reformas al servicio militar obligatorio, han disminuido la discrecionalidad en ciertos aspectos, pero como se ha evidenciado, en favor de ciertos grupos que no deberían verse favorecidos.

En este punto la indeterminación de "necesidades públicas" sostenida en el principio de interés general, puede entenderse como violación a derechos fundamentales, de aquellos a quienes se les afecta su dignidad humana, igualdad y libre desarrollo de la personalidad. Así lo ha manifestado, tímidamente la Corte Constitucional así: Los derechos a la vida y a la libertad no pueden sacrificarse por la persona en aras del interés general, salvo cuando la propia persona acepta el sacrificio voluntaria y libremente" (Corte Constitucional, Sentencia C-542 de 1993. M.P. Jorge Arango Mejía). 
Afirmaba Aristóteles en su Ética a Nicómaco, que la ciudad (Estado) es una entidad dinámica que tiende a conseguir un fin: la felicidad. Los hombres se asocian para vivir bien, para vivir conforme a la virtud, una vida regida por la razón. Esta tarea constituye el bien individual y comunitario.

La verdadera misión del Estado es la crear las condiciones para que los individuos tengan una vida buena y perfecta, es decir, que tiene que satisfacer las necesidades de los ciudadanos y velar para que la ciudad entera alcance la felicidad.

Para Aristóteles, la virtud de la justicia es la virtud propia de la comunidad política, porque es ésta la que establece el orden y la armonía en el conjunto social y la que expresa el bien común. Así, los elementos constitutivos del bien común son la justicia, la paz, la estabilidad y la seguridad.

La necesidad de la virtud de la justicia, obliga a respetar tanto los derechos como los deberes de los ciudadanos en relación con ese bien común. Y como esos derechos y deberes son esencialmente idénticos para todos los ciudadanos, el bien común implica un plano de igualdad para que este sea efectivamente comunicado a todos los miembros de la sociedad.

El bien común que suponen un bien general preestablecido y objetivo que no está ligado al consentimiento de los miembros de la sociedad o comunidad, pero al que estos deben sujetarse (Sánchez de la Barquera y Arroyo, 2016). 
El bien común, en sentido social, es aquel del que todos los miembros de una sociedad o comunidad de personas pueden beneficiarse. Es un conjunto de condiciones que permiten que las sociedades y sus miembros alcancen la felicidad como finalidad última del hombre. Es de advertir que no es necesario que todos los miembros de esa sociedad participen en este mismo bien común. Es decir que los integrantes de la sociedad tengan la posibilidad de participar del bien común, pero no deja de serlo, por la no participación efectiva de todos (Schultze, 2014).

Para Tomas de Aquino, el bien común no implica la suma de todos los bienes de todos los individuos de una sociedad, sin embargo, tiene un contenido fragmentario, que podemos estructurarlo, en tres elementos básicos: el bienestar material, la paz y los bienes culturales.

No obstante, podríamos afirmar que la esencia del bien común lo constituye el segundo de los elementos, es decir, la paz. Si la felicidad es el fin del Estado, la paz constituye un elemento esencial para lograr ese fin, por cuanto sin paz, la sociedad sería más aparente que efectiva, pues su unidad moral estaría internamente desgarrada, y una sociedad aparente nunca podrá brindar a sus miembros la felicidad, razón de ser de su existencia.

En torno a la ley en relación con el bien común, afirmaba Santo Tomás de Aquino que la "ley no es más que una prescripción de la razón, en orden al bien común, promulgada por aquel que tiene el cuidado de la comunidad". En la misma forma expresaba en la cuestión 98 de la Summa Teológica que "constituyéndose la ley ante todo por orden al bien común, cualquier otro precepto sobre un objeto particular no tiene razón de ley sino en cuanto se ordena al bien común. Por tanto, toda ley se ordena al bien común” 
En virtud de la ley se ordenan o disponen los individuos a la realización de la comunidad formada por ellos mismos. "La ley, ya sea natural o positiva, es un instrumento para la consecución de ese fin, en cuanto que expresa como han de disponerse adecuadamente las partes para constituir el todo que es la comunidad” (Poole, 2008, p.107).

La Carta Política de 1991 se refiere a esa realidad al establecer que "la soberanía reside exclusivamente en el pueblo, del cual emana el poder público" (Art. 3). De alguna manera podría decirse que, en nuestra Constitución el Estado, como titular del poder público, y su componente humano, el pueblo, están naturalmente fusionados.

"En el régimen que propone la Constitución que nos rige, el Estado sólo se justifica para alcanzar el bien común dentro de la garantía de los derechos fundamentales. No existe pues una prevalencia absoluta del interés general sobre el particular, pues tal prevalencia no puede obtenerse a costa del sacrificio de tales derechos". (Corte Constitucional, Sentencia C-251 de 2002. M.P. Eduardo Montealegre Lynett y Clara Inés Vargas Hernández).

En este punto es importante señalar, que toda la estructura constitucional, debería estar sustentada en el concepto de bien común, incluidas las tareas de defender la independencia nacional y las instituciones públicas, a través de la Fuerza Pública, constituida por las Fuerzas Militares y la Policía Nacional y que, en virtud de ello, en nombre del bien común, es necesario que los ciudadanos hagan ciertos sacrificios en el cumplimiento de sus deberes. 
Sin embargo, en nombre del bien común, solo son pocos y de esos pocos los menos favorecidos quienes asumen ciertas cargas en forma de obligaciones, como lo son las derivadas de la prestación efectiva del servicio militar obligatorio.

Con todo lo anterior, se puede determinar que el hecho de que el servicio militar ya no se preste en instituciones militares, y que las actividades adelantadas por los conscriptos en virtud de las prescripciones de la Ley 1816 de 2017, no respondan a las ordenadas por el artículo 216 Superior, implica un ejercicio arbitrario del legislador, que ha ejercido su facultad constitucional de expedir leyes, por fuera de los criterios propios del bien común, como el bienestar material, la paz y los valores culturales.

Para finalizar, podría entonces tajantemente afirmar, que se evidencian serias vulneraciones a principios y derechos fundamentales de nuestro ordenamiento jurídico con la estructuración en los términos actuales del régimen del servicio militar obligatorio establecido en la Ley 1816 de 2017. 


\section{CAPÍTULO III}

\section{ANÁLISIS ECONÓMICO DEL SERVICIO MILITAR OBLIGATORIO}

En este último capítulo se procederá a identificar los elementos esenciales del Análisis Económico del Derecho, como lo son la racionalidad, la eficiencia y entender las normas como un sistema de incentivos (precios), para luego proceder a aplicar concretamente dichos criterios en torno al servicio militar obligatorio, descrito en el primer capítulo, para determinar concretamente su eficiencia, con miras a garantizar el respeto de los principios y derechos constitucionales desarrollados en el segundo capítulo.

\subsection{Análisis Económico del Derecho}

\subsubsection{Generalidades}

La interacción entre el derecho y la economía, se puede entender como el reflejo de la relación directa de los individuos que frene a unas necesidades deben tomar unas decisiones económicas para satisfacer las primeras. Frente al tema Leguízamo (2007), establece:

"No es que la situación económica sea la causa, en el sentido de ser el único agente activo y que todo lo demás no sea sino un resultado pasivo. Se trata más bien de una acción reacción mutuas sobre la base de la necesidad económica, que en último término se impone siempre" (p. 136). 
El Análisis Económico del Derecho consiste, en términos generales, en la aplicación del análisis propio de las ciencias económicas al estudio del funcionamiento del sistema jurídico, de los problemas más importantes en el Derecho (Bullard, 2010). Por su parte, Rowley (1991), señala que el Análisis Económico del Derecho - AED, hace referencia a la aplicación de la teoría económica para examinar la formación, estructura, procesos e impacto del derecho y de las instituciones legales.

En concordancia con Posner (2011), el punto de partida es entender a la economía como una herramienta poderosa para analizar un amplio conjunto de asuntos y situaciones de tipo legal, pero desde una perspectiva diferente.

Márquez (2005) por su parte, define el Análisis Económico del Derecho como “la aplicación de la teoría económica y los métodos econométricos para examinar la formación, estructura, proceso y el impacto de la ley y las instituciones legales” (p. 41), que, al aplicarlo en las relaciones particulares, genera resultados jurídicos direccionados desde modelos económicos.

El Análisis Económico del Derecho, se puede traducir entonces, como la aplicación de los conceptos y métodos de la economía en el estudio del derecho. Al respecto, autores como Horwitz (1980), establecen que el derecho se vale de la economía para ser más "objetivo, neutral y apolítico" (p. 905). Sin embargo, otros autores consideran que los métodos de la economía sirven al derecho, para explicar y predecir las reacciones conductuales humanas ante las normas jurídicas (Lozano, 2016). 
Bajo esos postulados, se tiene que el Análisis Económico del Derecho se basa entonces en una relación costo-beneficio, aplicable tanto en el derecho público como en el derecho privado, en donde se consignan conceptos como la racionalidad, la eficiencia, la teoría de juegos, el Teorema de Coase, entre otros aspectos.

Así las cosas, se tiene que el Análisis Económico del Derecho implica una forma diferente de racionamiento, partiendo de parámetros distintos, para encontrar una respuesta a normas y/o situaciones con relevancia jurídica, razón por el cual, no puede ser considerado como una herramienta novedosa, sino más bien como un método tradicional, que trae componentes nuevos en diferentes escuelas como lo son el derecho la economía y las finanzas (Pinzón, 2010).

La corriente del Análisis Económico del Derecho, que se desarrolló principalmente en el sistema jurídico anglosajón, inicialmente se dedicó a la determinación de si sub-reglas específicas del common-law o legisladas, eran útiles para alcanzar los objetivos establecidos en ellas. La única función del análisis económico era la función de “establecer en qué medida los valores de carácter económico, pero legalmente establecidos, se estaban alcanzando en la práctica por las reglas secundarias y la legislación” (Calabresi, 1983, pág. 86).

El desarrollo del Análisis Económico del Derecho, llevó a utilizar los métodos de la economía para explicar y criticar las normas jurídicas incluso cuando no tienen un origen o un objetivo explícitamente. Diferentes corrientes dentro del AED, como la Escuela de Chicago, la Nueva Economía Institucional, la Escuela de la Elección Pública, han ido 
enriqueciéndolo como paradigma de investigación, complementando los vacíos existentes (Amador, 2012).

Su evolución, ha llevado a que al interior del Análisis Económico del Derecho existan dos diferentes enfoques metodológicos. Por una parte, el enfoque positivo; por la otra el enfoque normativo.

El enfoque positivo, utilizado para conocer de manera descriptiva los efectos económicos de una normatividad y medir su eficiencia; tal enfoque parte de la decisión racional de los agentes económicos de maximizar su bienestar y del entendimiento de las normas jurídicas como precios implícitos para determinadas conductas.

El enfoque de tipo normativo, responde a un análisis ex ante de las implicaciones de las normas jurídicas, que fungen como incentivos para el comportamiento de los diferentes agentes a quienes se encuentra dirigida y/o se ven afectados por la misma.

Podría decirse, que el Análisis Económico del Derecho, es una respuesta a las necesidades de los ordenamientos jurídicos, propios de las sociedades contemporáneas, analizar y dar solución a los grandes conflictos de intereses que se producen en la vida social, "no solo desde una perspectiva principalista, a la que tan acostumbrados estamos los juristas tradicionales, sino consecuencial: ¿Cuáles son las consecuencias -económicas y sociales- que producen las decisiones jurídicas legislativas o judiciales?” (Ariño, 2003, p. 74). 


\subsubsection{Presupuestos del Análisis Económico del Derecho}

El Análisis Económico del Derecho comprende tres presupuestos principales, los cuales constituyen los pilares teóricos para su aplicación sea desde el enfoque normativo o desde el enfoque positivo.

Estos presupuestos son: "la racionalidad del comportamiento de los individuos; la eficiencia como finalidad de las decisiones racionales y por último las normas jurídicas como mecanismos de incentivos traducibles a precios que inciden en la conducta de los individuos” (Posner, 2011, p. 44).

\subsubsection{Racionalidad del comportamiento de los individuos}

Como punto de partida, se puede establecer que la economía es la ciencia de la elección racional en un mundo donde los recursos son limitados en relación con las necesidades humanas. Es por ello que puede decirse que la economía estudia el comportamiento humano en busca de la satisfacción de las necesidades propias de cada individuo.

Al existir la necesidad y al ser escasos los recursos para satisfacer la misma, se materializa el comportamiento racional del individuo, que implica la toma de decisiones en términos económicos.

De acuerdo con Posner (2011), el sentido formal de la racionalidad que usa la teoría de la elección racional implica que las preferencias de los sujetos tienen las propiedades de ser completas (el sujeto las conoce y puede ordenarlas), reflexivas (implica que todo conjunto 
de preferencias, es al menos tan buena como sí misma), transitivas (si un sujeto prefiere una opción A antes que una opción B y una B antes que la C, entonces necesariamente preferirá también la opción A sobre la C) y continuas (si existen dos alternativas cercanas entre sí que ocupan una posición superior a otra, el individuo escogerá una de las dos).

Bajo ese entendido, cada individuo ordena sus preferencias en función de la utilidad que desean obtener tomando una decisión consciente y racional. Es por ello que en términos de maximizador racional, el individuo a través de su experiencia decide a priori sobre cuáles son los recursos y en qué medidas utilizarlos, a fin de satisfacer tales necesidades. Es decir se refiere a un análisis costo - beneficio.

El comportamiento del ser humano es racional, cuando se ajusta al modelo de la elección racional (Posner, 2007), es decir, como el principio de que el individuo toma la mejor decisión dentro del conjunto de decisiones posibles. El conjunto de posibilidades que enfrenta el individuo depende de las restricciones existentes, que pueden afectar tanto qué decisiones puede tomar, como cuáles son las consecuencias de esas decisiones tomadas (Streb, 1998).

Según los objetivos del agente, se puedan formular en términos monetarios o no monetarios, y se puede distinguir entre racionalidad en sentido limitado (maximización de beneficios) y racionalidad en sentido amplio (optimización de utilidad).

Como el Análisis Económico del Derecho, parte del análisis costo-beneficio, es imperativo identificar el denominado costo de oportunidad. El costo de oportunidad, como concepto económico, se refiere al costo o valor que se sacrifica por elegir una determinada 
alternativa y sacrificar las otras posibles decisiones (Mochón, 2005). Así las cosas, cada vez que un individuo toma una determinada decisión para satisfacer determinada necesidad, de manera intrínseca, implica la renuncia a la satisfacción de otra necesidad o de la misma necesidad en mayor o menor medida.

Bajo el criterio de racionalidad en sentido limitado (maximización de beneficios), y en relación con el servicio militar obligatorio, el concepto de costo de oportunidad se podría entender en los siguientes términos. Un conscripto, que debe incorporarse a la Fuerza Pública por el término de doce (12) meses, recibiendo una remuneración del treinta por ciento (30\%) de un salario mínimo mensual, no puede hacer parte activa del mercado laboral como empelado, en donde, como límite inferior, podría generar recursos equivalentes a los de un salario mínimo mensual. Es decir, su costo de oportunidad, en términos de remuneración es, del setenta por ciento (70\%), tomando como base un salario mínimo. Es de anotar, que podría obtener aún más que dicha remuneración, lo que haría que el costo de oportunidad se incrementara. Lo anterior sin analizar factores adicionales, como, por ejemplo, el tiempo de dedicación.

\subsubsection{Eficiencia como finalidad de las decisiones racionales}

El concepto de eficiencia ha estado asociado a la escuela utilitarista de Adam Smith, en el entendido que una situación es eficiente en la medida en que se maximice la riqueza de un cuerpo social sin tener a consideración las implicaciones del mismo. 
Al respecto, Posner (2011) indica que "el derecho común se explica mejor (no perfectamente), como un sistema para la maximización de las riquezas de la sociedad" (p.48). En este sentido, cuando se hace referencia a la eficiencia, debe tenerse en consideración el concepto intuitivo que estima el mencionado autor, conceptualizándolo como "la actividad que produce el nivel máximo posible de beneficio o la actividad que se desarrolla con los menores costos o minimizando costos” (p. 48).

Bajo esta perspectiva, el concepto de eficiencia, se encuentra generalmente relacionado con la ausencia de desperdicio. "Los economistas han perfeccionado este concepto, pero el significado principal para ellos es sin desperdicio de dinero" (Cooter, 2000, p. 133). "El desperdicio es, por ende, una irracionalidad que debe erradicarse del derecho y la política” (Cooter, 2000, p. 139).

Sin embargo, Morales de Setién (2011) sostiene que "el hecho de que los economistas y los juristas dedicados al análisis del derecho escojan la eficiencia como forma de valoración de los resultados de las conductas, no significa que la realidad tenga que ser necesariamente eficiente o que la eficiencia sea siempre deseable” (p. 47).

Frente a lo citado, se puede indicar que es eficiente la asignación de recursos escasos logrando el máximo de satisfacción individual y social, entendiéndose por bienestar social al conjunto de factores que participan en la calidad de la vida de la persona y que hacen que su existencia posea todos aquellos elementos que den lugar a la tranquilidad y satisfacción humana. 
Para comprender el concepto de eficiencia en el marco del Análisis Económico del Derecho, se debe analizar a partir de (por lo menos) dos criterios económicos: el óptimo de Pareto y el criterio Kaldor - Hicks.

El primer criterio, presenta un punto de equilibrio en donde existe eficiencia en el punto en el cual solo es posible mejorar la situación de un individuo afectando la situación de otro agente (Mochón, 2005). Por lo tanto, si un individuo que forma parte del sistema de distribución, producción y consumo mejora su situación sin perjudicar a otro nos encontraremos en situaciones no óptimas en el sentido paretiano.

Sin embargo, el óptimo paretiano no es sensible a los desequilibrios e injusticias en la asignación de recursos, conocidos como dotación inicial, sean estos factores, bienes o servicios, por lo tanto, podría entrar en conflicto con valores, principios e incluso derechos propios de un Estado Social de Derecho.

Bajo este postulado, el presente criterio no puede ser utilizado en un objeto de estudio como el derecho que tiene una naturaleza muy específica. Es por ello, que resulta útil el criterio de Kaldor - Hicks, puesto que parte de un supuesto más realista, al considerar que es más eficaz si en un resultado óptimo de Pareto, las ganancias del grupo beneficiado son superiores a las del grupo perjudicado (Posner, 2011).

Es decir, cuando se obtiene una compensación suficiente desde los que quedaran en una situación mejor a los que quedaran peor para que todos no terminen peor que antes. Así, lo relevante es que las ganancias, en términos de utilidad del grupo beneficiado, sean superiores a las del grupo perjudicado (Posner, 2011). 
El asunto clave resulta entonces en determinar si el beneficio que se deriva de la redistribución de recursos es mayor que la perdida que se genera por no hacerlo. Por ejemplo, en términos de daños, será necesario "decidir si el beneficio que se deriva de prevenir el daño es mayor que la perdida que tendría lugar para otros sujetos y relaciones sociales como resultado de interrumpir la acción que causa el daño” (Kitch, 2000, p. 58).

Aunque el ejercicio de compensación es más favorable y realista que el óptimo paretiano, el criterio dicho criterio económico de Kaldor - Hicks, tampoco es completamente conciliable, en términos generales, con conceptos como el de justicia propio de la ciencia jurídica. En este punto, podría complementarse con los postulados de justicia del trabajo de Rawls (2000).

Así, se tendría que las desigualdades sociales y económicas deben resolverse de modo tal que resulten en el mayor beneficio de los miembros menos aventajados de la sociedad, denominado principio de la diferencia. Con este postulado, no solo se cumpliría con el criterio de eficiencia, sino que además redundaría en el cumplimiento de los fines de un Estado Social de Derecho.

"Sería deseable que las únicas acciones desarrolladas fueran aquellas en las que lo que se ganase valiera más que lo que se perdiese. Pero al elegir entre arreglos sociales (...), debemos tener en mente que un cambio del sistema existente que conduzca a un mejoramiento en algunas decisiones puede muy bien conducir a un empeoramiento en otras, situación que hace necesario que la elección de los "arreglos sociales" para la solución de los problemas económicos, se efectúe de tal manera que tenga en cuenta los efectos que dichos arreglos pueden generar en las diferentes esferas de la vida. Al 
diseñar y elegir entre arreglos sociales debemos considerar el efecto total" (Coase, 2000, p. 555).

Lo anterior se complementaría por el principio de libertad planeado por Rawls (2000), en el que cada persona deberá tener un derecho igual al esquema más extenso de libertades básicas iguales, compatible con un esquema similar de libertades para otros individuos.

Desde la perspectiva del Análisis Económico del Derecho, que parte de un estudio de la relación costo-beneficio, entendiendo que, en la redistribución de riqueza, con la aplicación del criterio Kaldor-Hicks y las propuestas de Rawls, el individuo, maximizador racional, deberá analizar los costos en los que se incurrirían al momento de la redistribución y la decisión maximizadora, esta es la que genere una compensación mayor del perjuicio en torno al beneficio, deberá tener en cuenta los criterios de libertad y de la diferencia.

Así las cosas, de ser necesaria la reasignación de recursos, normalmente lo es, si el ingreso no puede ser redistribuido sin costo alguno, habrá un conflicto entre eficiencia y equidad, es decir, que, si el ingreso puede ser redistribuido sin costo alguno, no habrá un conflicto entre eficiencia y equidad.

Lo anterior se puede analizar desde el Teorema de Coase (Posner, 2011), que se refiere principalmente a los efectos de los costos de transacción en las medidas que se toman para la reasignación de recursos. Los costos de transacción, se puede indicar que éstos comprenden los costos de negociación, monitoreo, adquisición de información y ejecución forzosa de los acuerdos o los costos en los que incurre dos o más partes en el proceso de llegar a un acuerdo y velar por su cumplimiento, en general podríamos decir que se trata de 
los costos de establecer y mantener unos derechos de propiedad previamente determinados (Medellín 2013).

El Teorema de Coase se divide en dos partes. El primer postulado señala que en ausencia de los costos de transacción el derecho es irrelevante para la obtención de asignaciones eficientes de recursos. El segundo postulado establece que si los costos de transacción van a impedir celebrar una negociación que produzca una redistribución eficiente de los derechos, el sistema jurídico podría efectuar una asignación de derechos que condujera a la situación más eficiente (Coase, 2000).

Partiendo de la base de que un costo de transacción se refiere a cualquier costo relativo al establecimiento, mantenimiento o conservación de un derecho con valor económico, de acuerdo con Teorema de Coase, en ausencia de este tipo de costos, las partes intervinientes en un acuerdo llegarán siempre a la solución más eficaz con independencia de cuál sea la asignación inicial de derechos que haga un sistema jurídico (Posner, 2011).

Desde esta perspectiva, podría entenderse que un inadecuado desarrollo legislativo puede generar asignaciones ineficientes. Es por ello, que, al momento de legislar, se debe verificar si el establecimiento de costos de transacción está absolutamente justificado y por ende es necesario. Desde el derecho, se analizaría desde el denominado test de proporcionalidad, desde el AED, desde el criterio de eficiencia, el realizar el análisis costobeneficio de la medida. 


\subsubsection{Normas como Precio}

Desde la perspectiva del Análisis Económico del Derecho, el tercer supuesto, consiste en que las normas funcionan como sistemas de incentivos para sus destinatarios. En ese orden de ideas, los destinatarios de las normas, las cuales de una u otra manera tiene por finalidad que los sujetos adelanten o se abstengan de adelantar ciertas conductas, realizan un ejercicio racional de asignación de precios, cuando determinan el valor de cumplir o no la respectiva norma. Según Posner (2011), “el individuo considera entonces la norma como un precio que pondera en sus cálculos junto con otros precios que asigna a sus acciones, y deriva de ello la utilidad total esperada en sus acciones" (p.59).

Un individuo se motivaría a adelantar o no determinado comportamiento, según la valoración, precio, que le asigne a la consecuencia de cumplir o incumplir la norma, que no es otra cosa que el análisis de la relación de costo-beneficio, en términos de eficiencia.

Las normas, de acuerdo al incentivo que el legislador quiera dar, se considerarán precios positivos o negativos. Cuando el legislador quiere motivar al individuo para que adelante determinada conducta o se abstenga de hacerlo a través de incentivos, como un subsidio, premio o descuento, se considera que la norma corresponde a un precio positivo. Si, por el contrario, la motivación para que adelante o se abstenga de adelantar determinado comportamiento se prevé a través de sanciones, penas de prisión o multas, se refiere a un precio negativo. 
Entonces desde un enfoque normativo, desde el Análisis Económico del Derecho, se podría prever si un individuo, actuando como maximizador racional, se motivaría con la instauración de un precio negativo o positivo, teniendo en cuenta que el precio que debe pagar, intrínseco en la norma, por determinado comportamiento, responde al criterio de eficiencia en términos de costo-beneficio.

Es por ello, que el legislador, deberá tener en cuenta, al momento de la expedición de normas, que un individuo racional, para la toma de sus decisiones, valorará los costos y beneficios que conoce, entre ellos, el denominado costo de oportunidad.

\subsection{Análisis Económico del Servicio Militar Obligatorio}

El servicio militar obligatorio ha estado presente en nuestro ordenamiento jurídico constitucional por más de un Siglo. En términos generales, las decisiones del Estado respecto del funcionamiento de la economía y la organización de la sociedad constituyen una forma de regulación económica y social (Corte Constitucional, Sentencia C-150 de 2003. M.P. Manuel José Cepeda Espinosa).

Se podría afirmar que el Estado debe buscar la eficiencia en la administración de los recursos públicos y debe establecer las reglas de juego para que los recursos de los privados también tiendan a ser utilizados de la misma manera. Sin embargo, las economías raramente se encuentran en eficiencia.

"Existe ineficiencia siempre que los hombres y las máquinas se utilizan de tal manera que no se logra su pleno potencial de producción en la economía. Por lo tanto, un 
cambio en la asignación ineficiente a una asignación eficiente tiene como resultado, por definición, un aumento en la producción” (North, p. 74)

Sin embargo, esto lleva consigo ciertos costos y algunos verán perjudicada su situación. Por ello, un cambio de asignación no implica que todos vivan en mejores condiciones. Lo que es necesario entonces, es que se compensen esos perjuicios, partiendo del principio "que exista un mecanismo institucional por medio del cual se puede llevar el pago colateral de compensación” (North, p. 74).

El análisis de costos de la conscripción frente a la voluntariedad debe ser estudiado desde la perspectiva propia del modelo económico vigente en Colombia. Esto es una economía mixta de mercado, en la cual, por un lado, se entregan a los particulares, una serie de libertades económicas, consagradas en el artículo 333 de la Constitución Política como lo son la libertad de empresa y la libertad de competencia, que incorporan como prerrogativa la libertad contractual; y por otro, se establece la obligación de intervenir del Estado en la economía, estipulada en el artículo 334 Superior.

De lo anterior es supremamente importante entender, que el modelo económico establecido en la Constitución de 1991, privilegia la libertad de empresa, la cual consiste en la destinación de recursos, para "la realización de actividades económicas para la producción e intercambio de bienes y servicios conforme a las pautas o modelos de organización típicas del mundo económico contemporáneo con vistas a la 
obtención de un beneficio o ganancia" (Corte Constitucional, Sentencia C-263 de 2011. M.P. Jorge Ignacio Pretelt Chaljub).

Esta libertad de acuerdo con la jurisprudencia constitucional, comprende, entre otras garantías, la libre iniciativa privada y la libertad contractual. Lo anterior implica, entre otras prerrogativas, el derecho a un tratamiento igual y no discriminatorio entre empresarios o competidores que se hallan en la misma posición y el derecho a recibir un beneficio económico razonable (Corte Constitucional, Sentencia C-150 de 2003. M.P. Manuel José Cepeda Espinosa).

La aplicación de las herramientas del Análisis Económico del Derecho frente a las normas que establecen y configuran el servicio militar obligatorio en Colombia, se podría efectuar frente a los diferentes tipos de costos que se pueden presentar con la normatividad actual. Se podrían clasificar en costos de selección, costos de rotación, costos de diferenciación, costos de especialización y costos de ineficiencia en la tributación.

En relación con los costos de selección, frente al servicio militar, se podría entender al Estado, como reclutador, esto es, como si fuera una empresa en busca de mano de obra para su negocio. Los encargados del reclutamiento fungen el papel de gerentes que deben decidir cómo administrar los recursos para la compra de máquinas como alternativa a la contratación de personal.

De acuerdo con lo anterior, cuando las Fuerzas Armadas vincula soldados por un nivel de remuneración inferior al que incentivaría a que se vincularán 
voluntariamente, no existe para los gerentes una información adecuada sobre los costos de funcionamiento necesario para el cumplimiento de sus funciones y operaciones. En virtud de que la decisión se toma sin evaluar la verdadera necesidad de pie de fuerza, por un lado, se vincula más de lo requerido, para adelantar inclusive funciones accesorias en algunos casos innecesarias; por otro lado, las máquinas se utilizan menos que los hombres.

Un ejemplo muy concreto de esta situación tiene que ver con la Brigada de Brigada de Ingenieros de Desminado Humanitario $\mathrm{N}^{\circ} 1-\mathrm{BRDEH}$, que de acuerdo con la Dirección para la Acción Integral Contra Minas Antipersona - Descontamina Colombia (2017), cuenta con dos mil cuatrocientos veinte (2420) hombres, nueve (9) equipos barreminas, y cien (100) caninos. A pesar que el desminado manual implica mayores riesgos para las personas, apenas contamos con nueve (9) maquinas que no implican riesgo para la vida del operador, ya que se opera a control remoto.

Es más eficiente la utilización de máquinas, si el criterio fuera que el riesgo para la vida es mínimo, que es 6000 \% más rápida, pero como sus costos de adquisición y mantenimiento son mucho más altos, se privilegia el desminado manual, el cual debería ser una excepción. En esta situación, los militares "gerentes” prefieren utilizar hombres en esta labor en vez de máquinas.

Teniendo en cuenta que, como se ha indicado en el capítulo primero, la remuneración de los conscriptos es inferior a los precios corrientes del mercado de trabajo o por lo menos para incentivarlos a enrolarse voluntariamente, en la actualidad la remuneración para un 
soldado en el servicio militar obligatorio es del treinta por ciento $(30 \%)$ de un salario mínimo, está claro que las Fuerzas Armadas están utilizando demasiados hombres. Así, la relación hombre/máquina actual es una relación mucho mayor a la relación óptima. Esto socialmente es mucho más costoso a la sociedad para el nivel de gasto de defensa deseado.

Otro costo relevante hace referencia a la rotación del personal. Teniendo en cuenta que el servicio militar obligatorio tiene una duración dentro doce (12) y dieciocho (18) meses, el índice de rotación es muy elevado. El entrenamiento de los soldados implica por lo menos una fase de instrucción básica de tres (3) meses a seis (6) meses. Lo anterior implica el uso de maquinaria, armamento, munición, uniformes, personal para la instrucción e instalaciones necesarias para garantizar dicho entrenamiento constante. Adicionalmente, a lo anterior se le debe sumar los costos asociados al reclutamiento continuo de conscriptos para los contingentes.

Los costos de diferenciación, hacen referencia a la valoración que se tiene de cada conscripto. Con la lógica del sistema de mercado, todos estarían valuados en el mismo precio, ya que no existe una verdadera diferenciación al momento del reclutamiento. Es decir que, por regla general, todos desarrollan las mismas funciones. Y si existe selección, esta no se da por un verdadero proceso de clasificación, sino arbitrario y netamente subjetivo. Lo anterior en virtud de que la selección para que sean asignados a ciertas tares, no dependa de sus conocimientos previos o capacidades; mucho menos de la experiencia. 
Al igual que en una empresa, los gerentes militares deben dejarse guiar por las señales, pero en el caso del servicio militar dichas señales son difusas. La misma situación viven los conscriptos, ya que sus incentivos no se relacionan con la remuneración, ya que es la misma para todos, sino por las actividades o tareas que le serán asignadas o que cree que le sarán asignadas.

De nuevo el asunto es de experiencia. La subutilización del recurso es evidente, ya que la asignación en las Fuerzas Armadas, para el apoyo logístico, de inteligencia, caballería o cualquier otra especialidad o arma, no dependen de condiciones previas al reclutamiento del conscripto.

Frente a los costos de especialización se deriva principalmente de la situación anterior. Al no haber diferenciación, puede que se desperdicien recursos al momento de hacer el reparto en las diferentes especialidades.

Por ejemplo, si se asigna un conscripto a la Escuela de Comunicaciones que no tenga capacitación en electrónica, mientras que aquel que si la tiene es asignado a una unidad de policía militar. Es mucho más costoso, en términos de tiempo, capacitadores, instrumentos y materiales, capacitar a un neófito, que instruir en términos puntuales, tipos específicos de radios o equipos de comunicaciones, a un soldado que ya tiene previamente conocimientos en la materia. 
Si a esto se le suma que "la economía sufre un costo de oportunidad por cada conscripto, el cual es totalmente independiente de lo que se les paga a los conscriptos en el ejército" (North, p.77). Esto es, que, en términos de costo de oportunidad, la sumatoria del sacrificio individual de la oportunidad perdida de cada conscripto, en términos generales, los asume, toda la sociedad.

En ese orden de ideas, el nivel de producción de la economía disminuye, ya que la valoración del trabajo, como prestación de servicios, se refiere a la remuneración mensual que recibe como conscripto, $30 \%$ de un salario mínimo, y no a lo que recibiría por su actividad en el mercado.

Un mejoramiento de los niveles de eficiencia en las Fuerzas Armadas, requiere indiscutiblemente la disminución sustancial de la cantidad de soldados, "modificando los criterios tradicionales en cuanto al número de militares sobre el total de la población" (Cordero, 1989, p.56).

En relación con el punto anterior, aparecen los costos de ineficiencia en la tributación. Como se dijo, en términos generales, el costo de oportunidad es asumido por la economía. Pero, adicionalmente se debe tener en cuenta que el Estado, con recursos de tributación, paga apenas una parte de esos costos de oportunidad, en términos individuales, quien los asume, en su gran mayoría, es el conscripto. El internaliza esos costos durante el periodo en el que se encuentra prestando el servicio militar obligatorio. Esto no es otra cosa que un impuesto implícito, que equivale a la diferencia entre su salario o ingreso en la vida civil y la remuneración percibida en las Fuerzas Armadas. 
Este impuesto es un impuesto regresivo, ya que, como se ha manifestado en diferentes apartes de este documento, quienes por regla general terminan prestando servicio militar, son los pobres, debido a que las exenciones y aplazamientos, que terminan en exenciones favorecen esencialmente a las clases más favorecidas, sin perjuicio que se beneficien por diferentes factores también personas de las clases más bajas de la sociedad.

El principal de estos factores, es el relacionado con la posibilidad de aplazamiento y luego exención de la obligación de ingresar a las filas de las Fuerzas Armadas, de quienes acceden, especialmente, a las instituciones de educación superior y que corresponden concretamente a los estratos más altos de nuestra sociedad. Como se pudo verificar casi el $80 \%$ de los conscriptos pertenecen a los estratos 0,1 y 2 , mientras que no alcanza el $1 \%$ los que pertenecen a los estratos 5 y 6.

A pesar que, a quienes se exime de la prestación efectiva del servicio militar, se les exige una compensación que ingresa a las arcas del Estado, estos recursos no se trasladan a los conscriptos en los términos del análisis anterior. Por tal razón, es importante tener en cuenta lo manifestado por Vásquez (2016) quien concreta que:

“la población paga impuestos al Estado, entre otros propósitos, para su seguridad y esta contrata a quienes voluntariamente están dispuestos al posible sacrificio de sus vidas en el servicio militar, porque no siendo una obligación exigida y cumplida de manera igualitaria por todos, a nadie puede exigírsele el derecho a la seguridad a expensas de los otros" (p. 21) 


\subsection{Perspectivas y propuestas}

Como se ha podido determinar, el Análisis Económico del Derecho se basa en un análisis costo-beneficio, que pretende utilizar las herramientas de la economía, para que el derecho responda a los criterios de eficiencia, es decir, un derecho que evite el desperdicio de recursos, creando incentivos de conducta adecuados para lograr sus fines frente a todos los agentes.

Cordero (1989) manifiesta, que la concepción de un ejército de grandes dimensiones fortalece la idea de las Fuerzas Armadas “como un Estado dentro del Estado, lo que implica niveles de eficiencia negativos, por la asignación de importantes recursos a los aspectos administrativos en desmedro de los operativos" (p. 55).

Lo primero que se podría plantear, es que, manteniendo el servicio militar obligatorio, se modifiquen las reglas de exenciones y aplazamientos frente a la incorporación. Esto es, que quienes asuman los costos de ineficiencia en la tributación, no sean exclusivamente los ciudadanos de las clases menos favorecidas, sino que se trasfiera a todos y cada uno de los miembros de la sociedad, que, en principio, de acuerdo con las reglas constitucionales se encuentran obligados.

A pesar de ello, los costos de oportunidad se incrementarán en términos generales, aunque serán distribuidos en todas las clases sociales. Lo anterior es claramente ineficiente desde la perspectiva del Análisis Económico del Derecho. 
Sin embargo, esta solución implica profundizar los costos de diferenciación y de especialización, y mantiene los costos de selección y los costos de rotación. Entonces se requeriría, adicional a lo anterior, que se incluyeran criterios de incorporación para la asignación, lo que disminuiría los costos de diferenciación y especialización, aumentando los de selección. Por su parte, para diseminar los costos de rotación, se requeriría un aumento en el tiempo de servicio, lo que implicaría en un aumento constante en los costos de oportunidad para la sociedad en general.

Una propuesta alternativa, es la de eliminar la obligación de prestar servicio militar y se constituya en una decisión voluntaria. Lo anterior implicaría que la vinculación de soldados se incentive a través del aumento de los salarios hasta que se encuentre el punto de equilibrio para alcanzar el nivel de reclutas a incorporar.

Así los gerentes militares, disminuirían la relación hombre/maquina a un punto óptimo, caería la rotación de personal y los costos derivados de la misma, los soldados aplicarían a diferentes opciones que implica una utilización adecuada del recurso humano en virtud de las capacidades y la experiencia, haciendo cada vez más profesional las Fuerzas Armadas, es decir donde el producto marginal de cada individuo sea superior. Esto, en aplicación del tercer criterio del Análisis Económico del Derecho, en virtud del cual, las normas crean los suficientes incentivos para motivar a los ciudadanos a preferir la milicia frente al resto de actividades económicas 
Lo anterior, lleva a concluir que, de esta manera, los costos en los que se incurren con la conformación y mantenimiento de un ejército de voluntarios, analizando las diferentes variables en conjunto, son menores que los costos de uno de conscriptos. "El costo real de un ejército es el costo de oportunidad (alternativo) de todos los hombres y maquinas que el ejército utiliza” (North, p. 79).

Por tal razón, siempre va a existir ese costo de oportunidad, pero, la decisión de tener un ejército de voluntarios o no, se traduce concretamente en que parte de la sociedad va a asumir dichos costos. Hoy, en vigencia de la Ley 1816 de 2017, solamente una parte de los costos es asumida por los contribuyentes, mientras que la gran mayoría de los mismos, es asumida por los conscriptos, quienes como se ha dicho a lo largo del docuemnto, pertenecen a las clases menos favorecidas.

En síntesis, mantener el servicio militar obligatorio, con ciertas reformas, es inconveniente en términos de costos para la sociedad y la economía en general. Por otra parte, los costos de un ejército de voluntarios son asumido por todos. Esto es igualdad, solidaridad, es decir lo propio dentro de un Estado Social de Derecho.

La propuesta concreta entonces sería la derogatoria del servicio militar obligatorio y la implementación de reformas tendientes a la instauración de un modelo de Fuerzas Armadas compuestas exclusivas de voluntarios. Lo anterior sin prejuicio de la obligación de todos los colombianos de tomar las armas cuando las necesidades públicas así lo exijan. 


\section{CONCLUSIONES}

El servicio militar obligatorio es una institución que ha estado presente en todas las civilizaciones desde mucho tiempo atrás. Es una obligación en cabeza de todos o algunos de los miembros de las sociedades de propender, en una forma muy específica, por valores estatales de relevancia superior, como lo son la paz, la integridad territorial y la soberanía, entre otros.

A lo largo de la historia, pero específicamente en los últimos tiempos, dicha institución ha sufrido significativas modificaciones, al punto, que, en diferentes ordenamientos jurídicos, en diferentes latitudes ha desaparecido o ha sido reemplazada por un servicio de tipo social.

En Colombia, con la Ley 1816 de 2017, se ha mantenido la obligación de todos los colombianos de tomar las armas, cuando las circunstancias o necesidades públicas lo ameriten. Esta obligación se concreta, de manera clara, en los varones entre los dieciocho (18) y los veinticuatro (24) años de edad. Para las mujeres, el servicio es voluntario.

Sin embargo, con la evolución de normas y su respectiva interpretación jurisprudencial, existe un número, cada vez más creciente, de circunstancias que constituyen exenciones del cumplimiento material de dicha obligación. La principal de ellas, es la que tiene que ver con encontrarse adelantando estudios, en principio superiores. 
Este causal desde una perspectiva individual, es totalmente justificada. Si un ciudadano se encuentra adelantando estudios en primaria, media, secundaria o superiores, pareciera justificado que no cumpla con su obligación de prestar el servicio militar, entre otras cosas, por sus derechos constitucionales e inclusive la "utilidad" en términos generales a la sociedad que su preparación representa.

Sin embargo, es necesaria analizar dos elementos adicionales. Primero, la edad hasta la cual puede ser incorporado al servicio militar. Segundo, el grupo poblacional que puede acceder a la educación, en especial, a la superior, en nuestro país. Así las cosas, se puede concluir que quienes efectivamente prestan servicio militar, pertenecen, en su gran mayoría a los miembros de las clases menos favorecidas de la sociedad.

Adicionalmente, la Ley 1816 de 2017, desnaturaliza la obligación, en cabeza de todos los colombianos de prestar el servicio militar, ya que, en la actualidad, el servicio militar se puede prestar no solo en las Fuerzas Militares, sino en la Policía Nacional (Ley 48 de 1993), en el servicio nacional ambiental (Ley 99 de 1993) y en el Instituto Nacional Penitenciario INPEC (Ley 1816 de 2017). Entonces, se podría afirmar que, en parte su carácter y naturaleza dejo de ser militar, para convertirse en un servicio de otra índole.

Del análisis de la jurisprudencia constitucional colombiana, entorno al servicio militar obligatorio en relación con los principios y derechos constitucionales a la dignidad humana, la igualdad, el libre desarrollo de la personalidad, la solidaridad y el interés general sobre el particular, se pudo evidenciar que el régimen de servicio militar en Colombia, genera afectaciones injustificadas a varios de los mencionados principios. 
Por una parte, se evidencia claramente una afectación al derecho a la dignidad humana en sus tres aspectos fundamentales. Por una parte, en relación con la autonomía de las personas para diseñar un plan vital y de determinarse según sus características propias. Por otra los conscriptos, no deberían verse empobrecidos en el cumplimiento de sus obligaciones, situación que genera una carga desproporcional de obligaciones, rompiendo el núcleo esencial del derecho fundamental a la dignidad humana, en términos del mínimo vital.

Una "remuneración" que en la actualidad no constituye ni la tercera parte de un salario mínimo, claramente vulnera la dignidad humana en este aspecto tan relevante, si se tiene en cuenta, como se ha manifestado anteriormente, que, en Colombia, el servicio militar lo presta efectivamente, gran parte de los varones de las clases menos favorecidas.

Como se pudo establecer, el ordenamiento jurídico colombiano ha fijado la obligación "formal" de todos los colombianos de tomar las armas cuando las necesidades públicas lo exijan. Sin embargo, el régimen del servicio militar obligatorio afecta el derecho a la igualdad material, frente a las exenciones y aplazamientos, concretamente cuando el varón obligado se encuentra adelantando estudios de educación superior por cuando el acceso a dicha exención depende de sus recursos económicos y no de otra índole.

Frente al derecho al libre desarrollo de la personalidad, se puede identificar igualmente una afectación injustificada al obligar a jóvenes colombianos a ser instruidos en una doctrina a la cual no quieren acceder, pero que, en virtud de una obligación de ciudadanos, deben asumir. 
Teniendo en cuenta lo anterior, se puede concluir tajantemente, que se evidencia una violación a la Carta Política en múltiples aspectos, ya que la hoy vigente Ley 1861 de 2017, desnaturaliza la institución del servicio militar obligatorio asignándole finalidades por fuera de lo estipulado y desconociendo principios y derechos constitucionales, al ahondar la gravosa situación de los menos favorecidos agregándole una carga de manera exclusiva y excluyente.

En este punto es de anotar, que el objetivo principal de la presente investigación, hace referencia a solucionar la problemática que desde el derecho presenta un sistema de servicio militar obligatorio, con las herramientas del Análisis Económico del Derecho y no con los criterios jurídicos propios de la ciencia del Derecho.

Así las cosas, desde la perspectiva del Análisis Económico del Derecho, se puede afirmar, que mantener el sistema de servicio militar obligatorio es ineficiente. Lo anterior se colige, de analizar, manteniendo el servicio militar obligatorio, las posibles modificaciones para que la relación costo-beneficio fuera satisfactoria.

Por tal razón es imperativa la derogatoria del servicio militar obligatorio y la implementación de reformas tendientes a la instauración de un modelo de Fuerza Pública compuestas exclusivas de voluntarios y adicionalmente a ello, para garantizar los principios de solidaridad y de interés general, se debería incorporar el servicio civil, en términos de igualdad para todos los miembros de la sociedad, teniendo en cuentas las especiales condiciones socio económicas de cada uno de los asociados. 


\section{BIBLIOGRAFÍA}

\section{Textos}

- Álvarez, D. (1984) Diccionario del Sistema Político Español. Madrid: Akal.

- Amador, L. (2012). Serie de Derecho Económico: casos de estudio de aplicación del Análisis Económico del Derecho. Bogotá: Universidad Externado de Colombia.

- Aquino, S.T. (S.XIII) Summa Teologica. Madrid: Provincias Dominicas de España

- Ariño, G. (2003). Principios de Derecho Público Económico. Bogotá: Universidad Externado de Colombia.

- Aristóteles. (2016). Ética a Nicómaco. Platorm.

- Bullard, A. (2010). Análisis Económico del Derecho. Lima: Catalejo Jurídico

- Calabresi, G. y Hirschoff, JT. (1972). Toward a Test for Strict Liability in Torts. The Yale Law Journal, N. 81 (reproducido en Kuperberg-Beitz 1983, págs. 154-184).

- Coase, R. (2000). El Problema del Costo Social. En A. Roemer, Derecho y Economía: una revisión de la literatura (págs. 512-557). México: Fondo de Cultura Económica.

- Cooter, R. D. (2000). Las mejores leyes correctas: fundamentos axiológicos del Análisis Económico del Derecho. En A. Roemer, Derecho y Economía: una revisión a la literatura (págs. 133 - 158). México D.F.: Fondo de Cultura Económica.

- Cordero, F. (1989). Servicio Militar Obligatorio y relaciones cívico-militares en América Latina. Nueva Sociedad Nro.104, 51-61.

- Fernández, F. (2000). La mujer y las Fuerzas Armadas. Un estudio jurídico constitucional. VVAA: Mujer y Constitución en España. Madrid: Centro de Estudios Políticos y Constitucionales. 
- Fernández, F. (2012). La Solidaridad Como Principio Constitucional. UNED. Teoría y Realidad Constitucional, núm. 30, 2012, pp. 139-181.

- Hegel, G. (1968). Filosofía del Derecho. Buenos Aires: Claridad

- Horwitz, J. (1980). Law and Economics: Science or Politics?, Hoftstra Law Reviev, n. ${ }^{\circ} 8$, págs. $905-912$.

- Jiménez, J. J. (2011). Análisis Económico del Derecho, Método Investigación y Practica. Bogotá: Universidad Externado de Colombia.

- Kant, E. (1921). Fundamentación de la metafísica de las costumbres. Madrid: Ed. Pedro M. Rosario Barbosa.

- Kelman, M. (2011). La mala comprensión de la vida social: una crítica a las premisas fundamentales del Análisis Económico del Derecho. En C. Morales de Setién, Análisis Económico del Derecho (págs. 245 - 269). Bogotá: Siglo del Hombre.

- Kitch, E. W. (2000). Los Fundamentos Intelectuales del Análisis Económico del Derecho. En A. Roemer, Derecho y Economía una Revisión de la Literatura (págs. 51 - 65). México: Fondo de Cultura Económica.

- Leguízamo, W. (2007). Teorías y doctrina sobre las relaciones: del derecho y la economía. Revista Contexto, 11 - 28.

- Lence, C. (1995) La mujer en el ejército. Ministerio de Defensa Español p. 45-59.

- Lozano, E. (2016). Teoría y puesta en práctica del Análisis Económico del Derecho colombiano. Bogotá: Universidad de los Andes.

- Márquez, C. (2005) Anotaciones sobre Análisis Económico del Derecho Vol. I. Bogotá: Universidad Javeriana.

- Medellín, A. (2013). La ponderación y el Análisis Económico del Derecho. Bogotá: Universidad Externado de Colombia. 
- Mochón, F. (2005) Principios de Economía (3 $3^{\mathrm{a}}$ Ed.). Madrid: Editorial Mc Graw Hill.

- Morales de Setién, C. (2011). Las bases del análisis económico del derecho. En C. Morales de Setién, Análisis Económico del Derecho (págs. 11-76). Bogotá: Siglo del Hombre.

- North, D. (1976). El análisis económico de la usura, el crimen, la pobreza, etcétera. México: Fondo de Cultura Económica

- Oliver, J. (1996). Libertad de conciencia y servicio militar. Barcelona: Universitat de les Illes Balears. Working Paper No.116.

- Onfray, M. (2005). Antimanual de filosofia. Madrid : EDAF.

- Peces-Barba, G. (2007) La dignidad humana: Madrid, 2007. p. 155-172.

- Pinzón, M. (2010). Aproximaciones al Análisis Económico del Derecho. Bogotá: Universidad Externado de Colombia.

- Politica Exterior S.A. (1992). El servicio militar en la historia Política Exterior. Vol 6 (26), 190-195.

- Poole, D. (2008). Persona y Derecho. Madrid: Universidad Rey Juan Carlos.

- Posner, R. (2007) El Análisis Económico del Derecho. México: Fondo de Cultura Económica.

- Posner, R. Landes, W., Kelman, M. (2011) Análisis Económico del Derecho. Bogotá: Siglo del Hombre Editores.

- Rawls, J. (2000) Teoría de la Justicia. Barcelona: Editoral Bellaterra.

- Rengifo, D. (2016) Valor y precio de un soldado. El Tiempo, publicado el 08 de agosto de 2016. Bogotá. 
- Revorio, F. J. (2011). Derechos humanos y deberes fundamentales. Sobre el concepto de deber constitucional y los deberes en la Constitución Española de 1978. Ius Revista del Instituto de Ciencias Jurídicas de Puebla , 278-310.

- Reyes, C. (2017). Servicio Militar femenino de la Armada debutará en 2018. La Tercera, publicado el 29 de abril de 2017. Santiago.

- Rodríguez, E. (2016). Desigualdad en la prestación del servicio militar en Colombia. Universidad Militar Nueva Granada.

- Rowley, C. (1991). La elección pública y el análisis económico del derecho. Unirioja

- Rubio, F. (1995). Derechos Fundamentales y Principios Constitucionales. España: Ed. Ariel, Derecho, p. 110 -111.

- Sanabria, J. (2012). Derecho fundamental al mínimo vital: común denominador a los límites del Estado. Universidad de Cartagena.

- Sánchez de la Barquera y Arroyo, H. (2016) Antologías para el estudio y la enseñanza de la ciencia política. Volumen I: Fundamentos, teoría e ideas políticas. México: UNAM, Instituto de Investigaciones Jurídicas.

- Sánchez E, (2005). Servicio militar: un problema de identidades. Madrid: Universidad Complutense de Madrid.

- Streb, J. (1998). El significado de racionalidad en economía. Buenos Aires: Universidad del CEMA.

- Torres F. (2009) "El concepto de igualdad y los derechos humanos. Un enfoque de género”, en Zapateando 2, disponible en 〈http://bit.ly/1jgLM6U>, página consultada el 14 de diciembre de 2017.

- Trujillo, A, Palacios Lleras, A, Pinzón Camargo, M Y Rojas Vásquez, I. (2012). Serie de Derecho Económico, Casos de estudio de aplicación del Análisis Económico del Derecho. Bogotá: Universidad Externado de Colombia. 
- Vásquez, D. Tellez, R.v(2017). Del servicio militar obligatorio a la voluntariedad. Revista Virtual Via Inveniendi et Iudicandi , 12 (No 1), 11-35.

- Weber, Max. (1988) Gesammelte Aufsätze zur Wissenschaftslehr. J. Winckelmann (editor). Tübingen: UTB für Wissenschaft.

\section{Sentencias}

- Consejo de Estado, Sala de lo Contencioso Administrativo, Sección Tercera, Sentencia del 17 de abril de 2016. C.P. Marta Nubia Velásquez Rico.

- Corte Constitucional, Sentencia T-428 de 1992. M.P. Ciro Angarita Barón

- Corte Constitucional, Sentencia T-499 de 1992. M.P. Eduardo Cifuentes Muñoz

- Corte Constitucional, Sentencia T-591 de 1992. M.P. Jaime Sanin Greiffenstein

- Corte Constitucional, Sentencia T-224 de 1993. M.P. Vladimiro Naranjo Mesa

- Corte Constitucional, Sentencia C-542 de 1993. M.P. Jorge Arango Mejía

- Corte Constitucional, Sentencia C-221 de 1994. M.P. Carlos Gaviria Díaz

- Corte Constitucional, Sentencia T-429 de 1994. M.P. Antonio Barrera Carbonell

- Corte Constitucional, Sentencia C-511 de 1994. M.P. Fabio Morón Díaz

- Corte Constitucional, Sentencia C-237 de 1997. M.P. Carlos Gaviria Díaz

- Corte Constitucional, Sentencia C-481 de 1998. M.P. Alejandro Martínez Caballero

- Corte Constitucional, Sentencia T-798 de 1998. M.P. Vladimiro Naranjo Mesa

- Corte Constitucional, Sentencia C-053 de 2001. M.P. Cristina Pardo Schlesinger

- Corte Constitucional, Sentencia T-702 de 2001. M.P. Marco Gerardo Monroy Cabra

- Corte Constitucional, Sentencia T-1206 de 2001. M.P. Rodrigo Escobar Gil 
- Corte Constitucional, Sentencia C-251 de 2002. M.P. Eduardo Montealegre Lynett y Clara Inés Vargas Hernández

- Corte Constitucional, Sentencia T-881 de 2002 M.P. Eduardo Montealegre Lynett

- Corte Constitucional, Sentencia C-150 de 2003. M.P. Manuel José Cepeda Espinosa

- Corte Constitucional, Sentencia C-520 de 2003. M.P. Rodrigo Escobar Gil

- Corte Constitucional, Sentencia T-903 de 2003. M.P. Rodrigo Escobar Gil

- Corte Constitucional, Sentencia C-459 de 2005. M.P. Jaime Araujo Rentería

- Corte Constitucional, Sentencia T-1095 de 2005. M.P. Clara Inés Vargas Hernández

- Corte Constitucional, Sentencia C-621 de 2007. M.P. Rodrigo Escobar Gil

- Corte Constitucional, Sentencia C-722 de 2007. M.P. Clara Inés Vargas Hernández

- Corte Constitucional, Sentencia C-932 de 2007. M.P. Marco Gerardo Monroy Cabra

- Corte Constitucional, Sentencia C-335 de 2008. M.P. Humberto Sierra Porto

- Corte Constitucional, Sentencia C-540 de 2008. M.P. Humberto Antonio Sierra Porto

- Corte Constitucional, Sentencia C-755 de 2008. M.P. Nilson Pinilla Pinilla

- Corte Constitucional, Sentencia C-775 de 2008. M.P. Nelson Pinilla Pinilla

- Corte Constitucional, Sentencia T-218 de 2010. M.P. Gabriel Eduardo Mendoza Martelo

- Corte Constitucional, Sentencia C-263 de 2011. M.P. Jorge Ignacio Pretelt Chaljub

- Corte Constitucional, Sentencia C-879 de 2011. M.P. Humberto Antonio Sierra Porto

- Corte Constitucional, Sentencia T-774 de 2013. M.P. María Victoria Calle Correa 
- Corte Constitucional, Sentencia T-455 de 2014. M.P. Luis Ernesto Vargas Silva

- Corte Constitucional, Sentencia T-077 de 2016. M.P. Jorge Iván Palacio Palacio

- Tribunal Constitucional Federal Alemán, Sentencia de 16 de enero de1957 